\title{
Multi-model assessment of stratospheric ozone return dates and ozone recovery in CCMVal-2 models
}

\author{
V. Eyring ${ }^{1}$, I. Cionni ${ }^{1}$, G. E. Bodeker ${ }^{2}$, A. J. Charlton-Perez ${ }^{3}$, D. E. Kinnison ${ }^{4}$, J. F. Scinocca ${ }^{5}$, D. W. Waugh ${ }^{6}$, \\ H. Akiyoshi ${ }^{7}$, S. Bekki ${ }^{8}$, M. P. Chipperfield ${ }^{9}$, M. Dameris ${ }^{1}$, S. Dhomse ${ }^{9}$, S. M. Frith ${ }^{10}$, H. Garny ${ }^{1}$, A. Gettelman ${ }^{4}$, \\ A. Kubin ${ }^{11}$, U. Langematz ${ }^{11}$, E. Mancini ${ }^{12}$, M. Marchand ${ }^{8}$, T. Nakamura ${ }^{7}$, L. D. Oman ${ }^{13,6}$, S. Pawson ${ }^{13}$, G. Pitari ${ }^{12}$, \\ D. A. Plummer ${ }^{5}$, E. Rozanov ${ }^{14,15}$, T. G. Shepherd ${ }^{16}$, K. Shibata ${ }^{17}$, W. Tian ${ }^{9}$, P. Braesicke ${ }^{18}$, S. C. Hardiman ${ }^{19}$, \\ J. F. Lamarque ${ }^{4}$, O. Morgenstern ${ }^{18,20}$, J. A. Pyle ${ }^{18}$, D. Smale ${ }^{20}$, and Y. Yamashita ${ }^{21,7}$ \\ ${ }^{1}$ Deutsches Zentrum für Luft- und Raumfahrt, Institut für Physik der Atmosphäre, Oberpfaffenhofen, Germany \\ ${ }^{2}$ Bodeker Scientific, Alexandra, New Zealand \\ ${ }^{3}$ University of Reading, Department of Meteorology, Reading, UK \\ ${ }^{4}$ National Center for Atmospheric Research, Boulder, CO, USA \\ ${ }^{5}$ Environment Canada, Victoria, BC, Canada \\ ${ }^{6}$ Johns Hopkins University, Department of Earth and Planetary Sciences, Baltimore, Maryland, USA \\ ${ }^{7}$ National Institute for Environmental Studies, Tsukuba, Japan \\ ${ }^{8}$ Service d'Aeronomie, Institut Pierre-Simone Laplace, Paris, France \\ ${ }^{9}$ Institute for Climate and Atmospheric Science, University of Leeds, UK \\ ${ }^{10}$ Science Systems and Applications, Inc., Lanham MD 20706, USA \\ ${ }^{11}$ Freie Universität Berlin, Institut für Meteorologie, Berlin, Germany \\ ${ }^{12}$ Università L'Aquila, Dipartimento di Fisica, L'Aquila, Italy \\ ${ }^{13}$ NASA Goddard Space Flight Center, Greenbelt, Maryland, USA \\ ${ }^{14}$ Physikalisch-Meteorologisches Observatorium Davos/World Radiation Center, Davos, Switzerland \\ ${ }^{15}$ Institute for Atmospheric and Climate Science ETH, Zurich, Switzerland \\ ${ }^{16}$ University of Toronto, Department of Physics, Canada \\ ${ }^{17}$ Meteorological Research Institute, Tsukuba, Japan \\ ${ }^{18}$ University of Cambridge, Department of Chemistry, Cambridge, UK \\ ${ }^{19}$ Met Office, Exeter, UK \\ ${ }^{20}$ National Institute of Water and Atmospheric Research, Lauder, New Zealand \\ ${ }^{21}$ Center for Climate System Research, University of Tokyo, Japan
}

Received: 24 March 2010 - Published in Atmos. Chem. Phys. Discuss.: 3 May 2010

Revised: 15 July 2010 - Accepted: 21 September 2010 - Published: 7 October 2010

\begin{abstract}
Projections of stratospheric ozone from a suite of chemistry-climate models (CCMs) have been analyzed. In addition to a reference simulation where anthropogenic halogenated ozone depleting substances (ODSs) and greenhouse gases (GHGs) vary with time, sensitivity simulations with either ODS or GHG concentrations fixed at 1960 levels were performed to disaggregate the drivers of projected ozone changes. These simulations were also used to assess the
\end{abstract}

Correspondence to: V. Eyring

(veronika.eyring@dlr.de) two distinct milestones of ozone returning to historical values (ozone return dates) and ozone no longer being influenced by ODSs (full ozone recovery). The date of ozone returning to historical values does not indicate complete recovery from ODSs in most cases, because GHG-induced changes accelerate or decelerate ozone changes in many regions. In the upper stratosphere where $\mathrm{CO}_{2}$-induced stratospheric cooling increases ozone, full ozone recovery is projected to not likely have occurred by 2100 even though ozone returns to its 1980 or even 1960 levels well before ( 2025 and 2040, respectively). In contrast, in the tropical lower stratosphere ozone decreases continuously from 1960 to 2100 due to projected

Published by Copernicus Publications on behalf of the European Geosciences Union. 
increases in tropical upwelling, while by around 2040 it is already very likely that full recovery from the effects of ODSs has occurred, although ODS concentrations are still elevated by this date. In the midlatitude lower stratosphere the evolution differs from that in the tropics, and rather than a steady decrease in ozone, first a decrease in ozone is simulated from 1960 to 2000, which is then followed by a steady increase through the 21 st century. Ozone in the midlatitude lower stratosphere returns to 1980 levels by 2045 in the Northern Hemisphere (NH) and by 2055 in the Southern Hemisphere (SH), and full ozone recovery is likely reached by 2100 in both hemispheres. Overall, in all regions except the tropical lower stratosphere, full ozone recovery from ODSs occurs significantly later than the return of total column ozone to its 1980 level. The latest return of total column ozone is projected to occur over Antarctica ( 2045-2060) whereas it is not likely that full ozone recovery is reached by the end of the 21 st century in this region. Arctic total column ozone is projected to return to 1980 levels well before polar stratospheric halogen loading does so ( $\sim 2025-2030$ for total column ozone, cf. 2050-2070 for $\mathrm{Cl}_{\mathrm{y}}+60 \times \mathrm{Br}_{\mathrm{y}}$ ) and it is likely that full recovery of total column ozone from the effects of ODSs has occurred by $\sim 2035$. In contrast to the Antarctic, by 2100 Arctic total column ozone is projected to be above 1960 levels, but not in the fixed GHG simulation, indicating that climate change plays a significant role.

\section{Introduction}

Stratospheric ozone has been depleted by anthropogenic emissions of halogenated species over the last decades of the 20th century. In particular, emissions of anthropogenic halogenated ozone depletion substances (ODSs) whose production is controlled under the Montreal Protocol and its Amendments and Adjustments have increased stratospheric chlorine and bromine concentrations as measured by an increase in equivalent stratospheric chlorine (ESC; Eyring et al., 2007) and have dominated ozone loss in the recent past (Shepherd and Jonsson, 2008). Observations show that tropospheric halogen loading peaked around 1993 and is now decreasing (Montzka et al., 2003; WMO, 2007), reflecting the controls on ODS production by the Montreal Protocol. This slow decline is expected to continue through the 2st century in future emission projections that are consistent with current restrictions imposed by the Montreal Protocol, and ozone is expected to recover from the effect of ODSs as their concentrations reach their unperturbed values (Eyring et al., 2007; WMO, 2007). Atmospheric concentrations of longlived greenhouse gases (GHGs) have also increased and are expected to increase further in the future (IPCC, 2000, 2007; Moss et al., 2008) with consequences for the ozone layer. As stratospheric ODS concentrations slowly decline, effects of other processes such as $\mathrm{CO}_{2}$-induced cooling of the up- per and middle stratosphere that leads to increases in ozone due to slower gas-phase ozone loss cycles (Randeniya et al., 2002; Rosenfield et al., 2002; Haigh and Pyle, 1982), the acceleration of the Brewer-Dobson circulation or changes in transport (Garcia et al., 2007; Shepherd, 2008; Li and Austin, 2008; Butchart et al., 2006, 2010) are likely to play a more important role in the evolution of ozone through the 21 st century. In addition, increases in nitrous oxide $\left(\mathrm{N}_{2} \mathrm{O}\right)$ and methane $\left(\mathrm{CH}_{4}\right)$ could also impact ozone by accelerating catalytic ozone destruction cycles (e.g., Chipperfield and Feng, 2003; Ravishankara et al., 2009). The importance of these factors varies with region and time and thus the evolution of stratospheric ozone in the 21 st century also varies with region.

To project the future evolution of stratospheric ozone and attribute its behavior to different forcings, ChemistryClimate Models (CCMs) are widely used (e.g. Eyring et al., 2007; WMO, 2007). CCMs are three-dimensional atmospheric circulation models with fully coupled stratospheric chemistry, i.e. where chemical reactions drive changes in trace gas composition of the atmosphere which in turn change the atmospheric radiative balance and hence dynamics. Similarly, changes in dynamics and radiation feedback on chemistry. The pool of CCMs, and the number of simulations performed, has significantly deepened over the past four years. In particular simulations from $17 \mathrm{CCMs}$ that participated in the second round of coordinated model intercomparison organized by the Chemistry-Climate Model Validation (CCMVal) Activity (Eyring et al., 2005) (hereafter referred to as CCMVal-2) have been used to project the evolution of stratospheric ozone through the 21st century (Austin et al., 2010). These CCMs have also been extensively evaluated as part of the Stratospheric Processes And their Role in Climate (SPARC) CCMVal Report (SPARC CCMVal, 2010). Following the completion of the SPARC CCMVal Report, sensitivity simulations defined by Eyring et al. (2008) with either ODSs or GHGs fixed at 1960 levels have been completed by a subset of $11 \mathrm{CCMs}$. To quantitatively disaggregate the drivers of the projected ozone changes and to assess the full recovery of ozone from ODSs, these sensitivity simulations are analyzed here in addition to the future reference simulations.

The focus of the analysis is on the assessment of the two distinct milestones of ozone returning to historical values (ozone return dates) and ozone being no longer influenced by ODSs (full ozone recovery), following the definitions of the 2006 WMO/UNEP Scientific Assessment of Ozone Depletion (WMO, 2007). It is important to note that the date of ozone returning to historical values (e.g. mean 1960 or 1980 values) does not indicate complete recovery from ODSs in most cases, because GHG-induced changes accelerate or decelerate ozone changes in many regions. The first milestone (ozone return dates) can be evaluated directly from time series of simulated ozone. Evaluating return dates is relevant for gauging when the adverse impacts of enhanced 
surface ultraviolet radiation on human health and ecosystems caused by ozone depletion are likely to become negligible. Identifying the second milestone (full ozone recovery) requires an attribution of projected changes in ozone to different factors since ozone is not affected by ODSs alone. The required attribution can be obtained using CCM simulations with fixed ODSs or GHGs in combination with reference simulations that include all known forcings that affect ozone. Full ozone recovery has to date only been studied with a single model (Waugh et al., 2009), and it is important to test these findings in a multi-model framework. In addition, the 'no greenhouse-gas induced climate change' simulations with fixed GHGs were performed by single models to address the nonlinearity of ozone depletion/recovery and climate change (Garcia and Randel, 2008; Chapter 5 of WMO, 2007; Akiyoshi et al., 2010; McLandress et al., 2010).

The models and simulations are described in Sect. 2 and the method to generate the multi-model time series and associated uncertainties is described in Sect. 3. Section 4 uses the two sensitivity simulations with either ODSs or GHGs fixed at 1960 levels to attribute changes in the long-term ozone evolution to changes in ODSs and GHGs. Ozone return dates and the timing of full recovery of ozone from the effects of ODSs are discussed in Sect. 5. Section 6 closes with discussion and conclusions.

\section{Models and model simulations}

In the SPARC CCMVal Report on the evaluation of CCMs (SPARC CCMVal, 2010), 16 CCMs contributed a future reference simulation (REF-B2) to the CCMVal-2 activity and were used to project ozone through the 21 st century. In this study we have added a future reference simulation from the EMAC-FUB model. As a result, some of the results derived from the multi-model mean of the 17 reference simulations shown here differ slightly from those presented in SPARC CCMVal (2010). 11 CCM groups also performed additional simulations with GHGs or ODSs fixed at 1960 values which are used here to attribute changes in ozone to these two primary drivers and to assess the milestone of full ozone recovery. The participating CCMs are listed in Table 1 and are described in detail in the cited literature as well as in Morgenstern et al. (2010) and Chapter 2 of SPARC CCMVal (2010). It should be noted that only 1 of the 17 CCMs (CMAM) is coupled to an ocean in CCMVal-2, whereas in all other CCMs sea surface temperatures (SSTs) and sea ice concentrations (SICs) are prescribed. The CCMs have been extensively evaluated as part of the SPARC CCMVal Report. This comprehensive process-oriented validation has improved understanding of the strengths and weaknesses of CCMs and has been used to understand some of the source of the spread in model projections.

In total, $17 \mathrm{CCMs}$ provided reference simulations, 9 contributed a fixed ODS simulation (fODS), and 7 a fixed GHG simulation (fGHG). The model simulation design by each model group varied slightly. All are continuous simulations from 1960 to 2100, except that the REF-B2 and fGHG simulations by E39CA ended in 2050, REF-B2 by UMUKCAMETO ended in 2083, and the simulations by GEOSCCM combine a past (1960 to 2000) simulation forced by observed SSTs with a future (2000-2100) simulation so are not continuous. Specifics of the sensitivity simulations for the individual CCMs are summarized in Table 2, and are further detailed in Eyring et al. (2008). Their main characteristics are summarized below:

- REF-B2 is the so-called reference simulation and is a self consistent transient simulation from 1960 to 2100 . In this simulation the surface time series of halocarbons are based on the adjusted A1 scenario from WMO (2007). The adjusted A1 halogen scenario includes the earlier phase out of hydrochlorofluorocarbons (HCFCs) that was agreed to by the Parties to the Montreal Protocol in 2007. The long-lived GHG surface concentrations are taken from the SRES (Special Report on Emission Scenarios) GHG scenario A1B (IPCC, 2000). Except for one model (CMAM), SSTs and SICs are prescribed from coupled ocean model simulations, either from simulations with the ocean coupled to the underlying general circulation model, or from coupled oceanatmosphere models used in IPCC AR-4 simulations under the same GHG scenario. The reference simulation without natural variability is identical to the REF-B2 simulation defined in Eyring et al. (2008), while the one with forced natural variability is identical to SCN-B2d.

- fODS is a transient simulation from 1960 to 2100 similar to REF-B2, but with ODSs fixed at 1960 levels throughout the simulation. The simulation is designed to address the question of what are the effects of background halogens on stratospheric ozone and climate in the presence of increasing GHGs alone. By comparing fODS with REF-B2, the impact of halogens can be identified and, within the uncertainty associated with unforced inter-annual variability in ozone, it can be assessed at what point in the future the halogen impact on ozone is undetectable, i.e. when full recovery of ozone from the effects of ODSs occurs (WMO, 2007). The fODS simulation also permits an examination of how equivalent stratospheric chlorine (ESC) is affected by climate change alone. This sensitivity simulation is identical to the SCN-B2b simulation defined in Eyring et al. (2008). It should be noted that most models fixed halogens in the radiation and used GHGs and SSTs/SICs from REF-B2 (see Table 2). This introduces an inconsistency since with the absence of halogen-induced radiative forcing less near-surface warming in this experiment should be expected such that the SSTs/SICs from the REF-B2 simulations used in fODS are likely too warm. 
Table 1. A summary of the CCMs and simulations used in this study. REF-B2 is the future reference simulation, fODS is a simulation with fixed ODSs and fGHG a simulation with fixed GHGs. Further details on the models can be found in Morgenstern et al. (2010) and SPARC CCMVal (2010) as well as in the references given below. CCMs that contributed sensitivity simulations are highlighted in bold. N $\times$ REF-B2 means that the group provided $\mathrm{N}$ realizations of this simulation. T42 approximately corresponds to $2.8^{\circ} \times 2.8^{\circ}, \mathrm{T}^{\circ} 0$ to $3.75^{\circ} \times 3.75^{\circ}$.

\begin{tabular}{|c|c|c|c|c|c|c|c|c|}
\hline & $\mathrm{CCM}$ & Group and Location & Horiz. Res. & $\begin{array}{l}\text { Uppermost } \\
\text { computational } \\
\text { level }\end{array}$ & REF-B2 & fODS & fGHG & References \\
\hline 1 & AMTRAC3 & GFDL, USA & $\sim 200 \mathrm{~km}$ & $0.017 \mathrm{hPa}$ & REF-B2 & - & - & Austin and Wilson (2009) \\
\hline 2 & CAM3.5 & NCAR, USA & $1.9^{\circ} \times 2.5^{\circ}$ & $3.5 \mathrm{hPa}$ & REF-B2 & - & - & Lamarque et al. (2008) \\
\hline 3 & CCSRNIES & NIES, Tsukuba, Japan & $\mathrm{T} 42$ & $0.012 \mathrm{hPa}$ & REF-B2 & fODS & fGHG & Akiyoshi et al. (2009) \\
\hline 4 & CMAM & $\begin{array}{l}\text { MSC, University of Toronto, } \\
\text { York Univ., Canada }\end{array}$ & $\mathrm{T} 31$ & $0.00081 \mathrm{hPa}$ & $3 \times$ REF-B2 & $3 \times$ fODS & $3 \times \mathrm{fGHG}$ & $\begin{array}{l}\text { Scinocca et al. (2008); } \\
\text { deGrandpre et al. (2000) }\end{array}$ \\
\hline 5 & CNRM-ACM & Meteo-France; France & $\mathrm{T} 63$ & $0.07 \mathrm{hPa}$ & REF-B2 & - & - & $\begin{array}{l}\text { Déqué (2007); } \\
\text { Teyssèdre et al. (2007) }\end{array}$ \\
\hline 6 & E39CA & DLR, Germany & $\mathrm{T} 30$ & $10 \mathrm{hPa}$ & $\begin{array}{l}\text { REF-B2 (with solar } \\
\text { cycle \& QBO) }\end{array}$ & - & fGHG & $\begin{array}{l}\text { Stenke et al. (2009); } \\
\text { Garny et al. (2009) }\end{array}$ \\
\hline 7 & EMAC-FUB & FU Berlin, Germany & $\mathrm{T} 42$ & $0.01 \mathrm{hPa}$ & $\begin{array}{l}\text { REF-B2 (with solar } \\
\text { cycle \& QBO) }\end{array}$ & - & fGHG & $\begin{array}{l}\text { Jöckel et al. (2006); } \\
\text { Nissen at al. (2007) }\end{array}$ \\
\hline 8 & GEOSCCM & NASA/GSFC, USA & $2^{\circ} \times 2.5^{\circ}$ & $0.015 \mathrm{hPa}$ & REF-B2 & fODS & - & Pawson et al. (2008) \\
\hline 9 & LMDZrepro & IPSL, France & $2.5^{\circ} \times 3.75^{\circ}$ & $0.07 \mathrm{hPa}$ & REF-B2 & fODS & - & Jourdain et al. (2008) \\
\hline 10 & MRI & MRI, Japan & $\mathrm{T} 42$ & $0.01 \mathrm{hPa}$ & $2 \times$ REF-B2 & fODS & fGHG & Shibata and Deushi (2008a;b) \\
\hline 11 & NIWA-SOCOL & NIWA, NZ & $\mathrm{T} 30$ & $0.01 \mathrm{hpa}$ & REF-B2 & - & - & $\begin{array}{l}\text { Schraner et al. (2008); } \\
\text { Egorova et al. (2005) }\end{array}$ \\
\hline 12 & SOCOL & $\begin{array}{l}\text { PMOD/WRC and IAC ETHZ, } \\
\text { Switzerland }\end{array}$ & $\mathrm{T} 30$ & $0.01 \mathrm{hPa}$ & $3 \times$ REF-B2 & fODS & - & $\begin{array}{l}\text { Schraner et al. (2008); } \\
\text { Egorova et al. (2005) }\end{array}$ \\
\hline 13 & ULAQ & University of L'Aquila, Italy & $\mathrm{R} 6 / 11.5^{\circ} \times 22.5^{\circ}$ & $0.04 \mathrm{hPa}$ & $3 \times$ REF-B2 & fODS & fGHG & $\begin{array}{l}\text { Pitari et al. (2002); } \\
\text { Eyring et al. }(2006,2007)\end{array}$ \\
\hline 14 & UMSLIMCAT & University of Leeds, UK & $2.5^{\circ} \times 3.75^{\circ}$ & $0.01 \mathrm{hPa}$ & REF-B2 & fODS & - & $\begin{array}{l}\text { Tian and Chipperfield (2005); } \\
\text { Tian et al. (2006) }\end{array}$ \\
\hline 15 & UMUKCA-METO & MetOffice, UK & $2.5^{\circ} \times 3.75^{\circ}$ & $84 \mathrm{~km}$ & REF-B2 & - & - & Morgenstern et al. $(2008,2009)$ \\
\hline 16 & UMUKCA-UCAM & $\begin{array}{l}\text { University of Cambridge, } \\
\text { UK and NIWA, NZ }\end{array}$ & $2.5^{\circ} \times 3.75^{\circ}$ & $84 \mathrm{~km}$ & REF-B2 & - & - & Morgenstern et al. $(2008,2009)$ \\
\hline 17 & WACCM & NCAR, USA & $1.9^{\circ} \times 2.5^{\circ}$ & $5.9603 \cdot 10^{-6} \mathrm{hPa}$ & $3 \times$ REF-B2 & fODS & fGHG & Garcia et al. (2007) \\
\hline
\end{tabular}

- fGHG is a transient simulation from 1960 to 2100, similar to REF-B2, but with GHGs fixed at 1960 levels throughout the simulation. To be consistent with the GHG evolution, SSTs and SICs are prescribed with the 1955-1964 average of the values used in REF-B2. Whether or not the chemical effects of $\mathrm{CH}_{4}$ and $\mathrm{N}_{2} \mathrm{O}$ on ozone were also fixed at 1960 levels varied between the different modeling groups (see Table 2). The intention of the fGHG simulation was that the ODSs (in particular the CFCs) should also not contribute to radiative forcing. However, in a number of CCMs it was only the radiative forcing for $\mathrm{CO}_{2}, \mathrm{CH}_{4}$ and $\mathrm{N}_{2} \mathrm{O}$ that was held constant at 1960 values. The simulation is designed to assess the impact of climate change on ozone through the 21 st century. By comparing the sum of fGHG and fODS (each relative to the 1960 baseline) with REF-B2, the linear additivity of the responses can be assessed. This sensitivity simulation is identical to the SCN-B2c simulation defined in Eyring et al. (2008).

\section{Analysis method for multi-model time series}

The same time series additive model (TSAM) as used in Chapter 9 of SPARC CCMVal (2010) and described further in Scinocca et al. (2010) is used here to calculate multimodel trends and their confidence and prediction uncertainties. Here, the term 'trend' does not denote the result of a linear regression analysis but rather it refers to a smooth trajectory passing through the model time series representing the "signal" resulting from forced changes and leaving 'noise' as a residual resulting from internal unforced climate variability. The advantages of the TSAM approach are the production of smooth trend estimates out to the ends of the time series, the ability to model explicitly inter-annual variability about the trend estimate, and the ability to make rigorous probability statements (Scinocca et al., 2010).

The TSAM method consists of three different steps: (i) nonparametric estimation of the individual model trends (IMT), where the time series is additively modelled as the sum of a smooth unknown model-dependent trend and irregular normally-distributed noise which represents natural variability about the trend; (ii) baseline adjustment of these individual model trends so that they equal zero in the reference year (here 1960 or 1980); (iii) average of the baselineadjusted IMT estimates over all models resulting in a multimodel trend (MMT) estimate for each simulation. Both the IMT and MMT estimates pass through zero at the specified reference year. 
Table 2. Specifics of the sensitivity simulations with fixed ODSs (fODS) and fixed GHGs (fGHG).

\begin{tabular}{|c|c|c|c|c|c|c|}
\hline \multirow[t]{2}{*}{$\mathrm{CCM}$} & \multicolumn{3}{|c|}{ fODS } & \multicolumn{3}{|c|}{ fGHG } \\
\hline & $\begin{array}{l}\text { Halogens fixed at } 1960 \\
\text { levels for chemistry }\end{array}$ & $\begin{array}{l}\text { Halogens fixed at } 1960 \\
\text { levels for radiation }\end{array}$ & SSTs/SICs & $\begin{array}{l}\text { GHGs fixed at } 1960 \\
\text { levels for chemistry }\end{array}$ & $\begin{array}{l}\text { GHGs fixed at } 1960 \\
\text { levels for radiation }\end{array}$ & SSTs/SICs \\
\hline CCSRNIES & YES & YES & REF-B2 & $\begin{array}{l}\text { YES for } \mathrm{CO}_{2} \text {, } \\
\mathrm{CH}_{4} \text {, and } \mathrm{N}_{2} \mathrm{O}\end{array}$ & $\begin{array}{l}\text { YES for } \mathrm{CO}_{2} \text {, } \\
\mathrm{CH}_{4} \text {, and } \mathrm{N}_{2} \mathrm{O}\end{array}$ & $\begin{array}{l}\text { REF-B2 1955-1964 } \\
\text { mean }\end{array}$ \\
\hline CMAM & YES & NO & Coupled ocean & NO & $\begin{array}{l}\text { YES for } \mathrm{CO}_{2}, \mathrm{CH}_{4}, \\
\mathrm{~N}_{2} \mathrm{O}, \mathrm{F} 11 \text {, and } \mathrm{F} 12\end{array}$ & Coupled ocean \\
\hline E39CA & - & - & - & $\begin{array}{l}\text { YES for } \mathrm{CO}_{2} \text { and } \mathrm{CH}_{4} \\
\text { but } \mathrm{NO} \text { for } \mathrm{N}_{2} \mathrm{O}\end{array}$ & $\begin{array}{l}\text { YES for } \mathrm{CO}_{2} \\
\mathrm{CH}_{4}, \text { and } \mathrm{N}_{2} \mathrm{O}\end{array}$ & $\begin{array}{l}\text { REF-B2 1955-1964 } \\
\text { mean }\end{array}$ \\
\hline EMAC-FUB & - & - & - & $\begin{array}{l}\text { YES for } \mathrm{CO}_{2} \text {, } \\
\mathrm{CH}_{4} \text {, and } \mathrm{N}_{2} \mathrm{OCH}_{4} \text {, and } \mathrm{N}_{2} \mathrm{O}\end{array}$ & YES for $\mathrm{CO}_{2}$, & $\begin{array}{l}\text { REF-B2 1955-1964 } \\
\text { mean }\end{array}$ \\
\hline GEOSCCM & YES & YES & Hadley Obs/NCAR CCSM3 & - & - & - \\
\hline LMDZrepro & YES & YES & Same as REF-B2 & - & - & - \\
\hline MRI & YES & $\begin{array}{l}\text { Radiation code } \\
\text { does not treat } \\
\text { halogens }\end{array}$ & Same as REF-B2 & $\begin{array}{l}\text { YES for } \mathrm{CO}_{2} \text {, } \\
\mathrm{CH}_{4} \text {, and } \mathrm{N}_{2} \mathrm{O}\end{array}$ & $\begin{array}{l}\text { YES for } \mathrm{CO}_{2} \text {, } \\
\mathrm{CH}_{4} \text {, and } \mathrm{N}_{2} \mathrm{O}\end{array}$ & $\begin{array}{l}\text { REF-B2 1955-1964 } \\
\text { mean }\end{array}$ \\
\hline SOCOL & YES & YES & Same as REF-B2 & - & - & - \\
\hline ULAQ & YES & NO & Same as REF-B2 & NO & $\begin{array}{l}\text { YES for } \mathrm{CO}_{2} \text {, } \\
\mathrm{CH}_{4} \text {, and } \mathrm{N}_{2} \mathrm{O}\end{array}$ & $\begin{array}{l}\text { REF-B2 1955-1964 } \\
\text { mean }\end{array}$ \\
\hline UMSLIMCAT & YES & YES & Same as REF-B2 & - & - & - \\
\hline WACCM & YES & YES & Same as REF-B2 & $\begin{array}{l}\mathrm{YES} \text { for } \mathrm{CO}_{2} \\
\mathrm{CH}_{4} \text {, and } \mathrm{N}_{2} \mathrm{O}\end{array}$ & $\begin{array}{l}\mathrm{YES} \text { for } \mathrm{CO}_{2} \text {, } \\
\mathrm{CH}_{4}, \text { and } \mathrm{N}_{2} \mathrm{O}\end{array}$ & $\begin{array}{l}\text { REF-B2 1955-1964 } \\
\text { mean }\end{array}$ \\
\hline
\end{tabular}

Two types of uncertainty intervals are constructed for the MMT estimate. The first is the point-wise $95 \%$ confidence interval. This interval has a $95 \%$ chance of overlapping the true trend representing the local uncertainty in the trend at each year. The second interval is the $95 \%$ prediction interval which, by construction, is larger than the confidence interval. This interval is a combination of uncertainty in the trend estimate and uncertainty due to natural inter-annual variability about the trend and gives a sense of where an ozone value for a given year might reasonably lie.

Some CCMs submitted more than one reference simulation (CMAM, MRI, SOCOL, ULAQ, and WACCM). In such cases the nonparametric regression is applied to the raw time series from all ensemble members to calculate a single IMT which then contributes to the multi-model mean.

To illustrate the TSAM technique, the individual IMT and MMT estimates of the global total column ozone anomaly time series for the 17 reference simulations (REF-B2) are shown in Fig. 1 (similar figures for individual regions are shown in Figs. S1 and S2 in the supplementary online material). While the 1980 return date (red vertical lines) is the same in both panels, the uncertainty (blue vertical lines) in return dates derived from the 1960 baseline adjusted column ozone anomalies is slightly larger (by up to 3 years). A summary of the dates when total column ozone returns to its 1980 values, calculated from the two different time series, is given in Table 3. For consistency with the analysis presented in WMO (2007), 1980 ozone return dates in the reference simulations (Sect. 5) were calculated from the 1980-baseline adjusted time series. However, when using the fixed ODS and fixed GHG simulations to disentangle the effects of changes in climate and ODSs on ozone (Sect. 4) and to calculate dates of full recovery of ozone from the effects of ODSs (Sect. 5), the 1960-baseline adjusted time series are used since ODSs and GHGs are fixed at 1960 values and thus the ozone time series are already quite different from the REF-B2 simulations by 1980 .

\section{Long-term ozone evolution and attribution to different forcings}

To attribute long-term changes in ozone to GHGs and ODSs, in this Section the evolution of ozone in the reference simulations (REF-B2) is compared to the fixed ODS (fODS) and to the fixed GHG (fGHG) simulations. The evolution from 1960 to 2100 is assessed in the context of the 1960 baseline-adjusted ozone, temperature, transformed Eulerian mean vertical velocity $\left(w^{*}\right)$, and total column ozone time series (Figs. 2, 3, 5, 6, 8, and 9). In addition ozone and total column ozone are plotted against equivalent stratospheric chlorine (ESC, Figs. 4 and 7) using the absolute values rather than anomalies. The figures in the main paper show the 1960baseline adjusted multi-model trend estimates for the reference and sensitivity simulations, while the individual model trend estimates are shown in the figures in the supplementary online material (Figs. S3-13). The absolute values for each model in various regions and altitudes are shown in Fig. S14 to S38 in the supplementary online material. The analysis focuses on ozone in the upper $(5 \mathrm{hPa})$ and lower stratosphere $(50 \mathrm{hPa})$ as well as on total column ozone. The 5 and $50 \mathrm{hPa}$ levels are representative for the upper and lower stratosphere, respectively. They are chosen because of the difference between chemical and dynamical control and because previous studies have shown that the ozone evolution differs 
Table 3. Date of return to 1980 total column ozone in the reference simulations as derived from Fig. 10.

\begin{tabular}{lcccc}
\hline Region & $\begin{array}{c}\text { Year of baseline } \\
\text { adjustment }\end{array}$ & $\begin{array}{c}\text { Year when MMT ozone } \\
\text { returns to 1980 value }\end{array}$ & $\begin{array}{c}\text { Year when lower bound } \\
\text { of error bar returns to 1980 }\end{array}$ & $\begin{array}{c}\text { Year when upper bound of } \\
\text { error bar returns to 1980 }\end{array}$ \\
\hline Global annual mean & 1960 & 2032 & 2024 & 2042 \\
Tropics annual mean & 1980 & 2032 & 2027 & 2038 \\
& 1960 & 2043 & 2023 & - \\
Midlatitude NH annual mean & 1980 & 2042 & 2028 & 2029 \\
& 1960 & 2021 & 2017 & 2026 \\
Midlatitude SH annual mean & 1980 & 2021 & 2027 & 2043 \\
& 1960 & 2035 & 2030 & 2040 \\
Antarctic October mean & 1980 & 2035 & 2046 & 2060 \\
Arctic March mean & 1960 & 2051 & 2020 & 2057 \\
& 1980 & 2051 & 2023 & 2034 \\
\hline
\end{tabular}

significantly between the upper and lower stratosphere, with mostly little change in between (e.g., Eyring et al., 2007).

\subsection{Tropical ozone}

In the tropical upper stratosphere, all REF-B2 simulations indicate decreasing annual mean ozone between 1960 and 2000 followed by a steady increase until the end of the 21 st century, while in the tropical lower stratosphere continuous ozone decreases from 1960 to 2100 are simulated in all models (black line and grey shaded area in Fig. 2a and b; see also Chapter 9 of SPARC CCMVal, 2010; Austin et al., 2010 and Oman et al., 2010b).

\subsubsection{Tropical upper stratospheric ozone}

The elevated ozone in the tropical upper stratosphere at $5 \mathrm{hPa}$ after 2000 (Fig. 2a) results from a continuous cooling caused by increasing GHGs, in particular $\mathrm{CO}_{2}$ (Clough and Iacono, 1995). This continuous cooling is simulated in the multi-model trend estimate of REF-B2 (Fig. 3a) and slows gas-phase ozone loss cycles, thereby increasing ozone (e.g., Haigh and Pyle, 1982; Rosenfield et al., 2002; Jonsson et al., 2004). The cooling is very similar in the fODS simulation, whereas in the fGHG simulation temperature stay nearly constant over the simulated period because GHGs are fixed at 1960 levels and SSTs/SICs are forced to represent 1960 conditions (Fig. 3a). Consistently, the multi-model ozone trend of the fGHG simulation in the tropical upper stratosphere in Fig. 2a does not show the increase above 1980 values that is simulated in REF-B2, confirming that the CCMs are able to simulate the mechanism invoked above. In contrast, in the fODS simulation, a steady increase in tropical upper stratospheric ozone is simulated over the entire 1960 to 2100 period. At the end of the 21 st century, upper stratospheric ozone in the fGHG simulation is significantly lower than in the REF-B2 simulation, which in turn is only slightly smaller than in the fODS simulation (Fig. 2a).

The model time series plotted in Figs. 2 and 3 can be presented in an alternative format by plotting ozone as a function of ESC rather than time. This provides a different view on how past and future ozone changes respond to the primary driver of interest, i.e. changes in stratospheric halogen loading. An attribution of ozone changes in the tropical upper stratosphere to changes in ODSs and GHGs is displayed in this alternative format in Fig. 4a. The multi-model mean shown in this panel is calculated from the CCSRNIES, MRI, and WACCM models. CMAM was excluded from this multimodel mean since the CMAM fGHG simulation included the transient chemical effects of $\mathrm{CH}_{4}$ and $\mathrm{N}_{2} \mathrm{O}$ which cause the 2000 to 2100 fGHG trace to lie below the 1960 to 2000 trace in contrast to the other models used in the multi-model mean which show close concurrence between the 1960-2000 and 2000-2100 segments of the fGHG plot (see Figs. S14 to S18 in supplementary online material). Furthermore, ULAQ was excluded from this multi-model mean since it too showed behavior quite different to the other four models, including disagreement between the 1960-2000 and 2000-2100 segments in the fGHG simulation (see figures in the supplementary online material).

The multi-model mean REF-B2 simulation in Fig. 4a shows that ozone decreases from 1960 to 2000 in the upper stratosphere in response to increasing ESC. However, as ESC decreases from 2000 to 2100 ozone does not simply retrace the 1960-2000 path but shows systematically elevated ozone through the 21 st century such that ozone returns to 1980 values in the late 2020s well before ESC returns to its 1980 value in the mid-2050s. As discussed above, the elevated ozone through the 21 st century results from $\mathrm{CO}_{2}-$ 


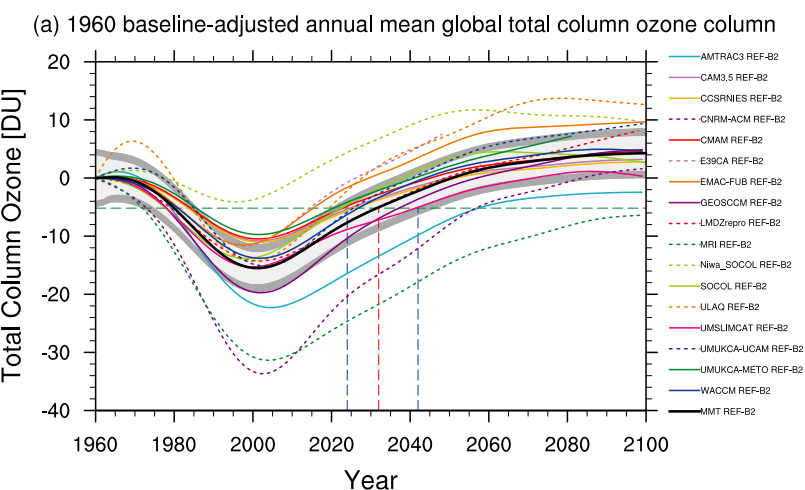

(b) 1980 baseline-adjusted annual mean global total column ozone column

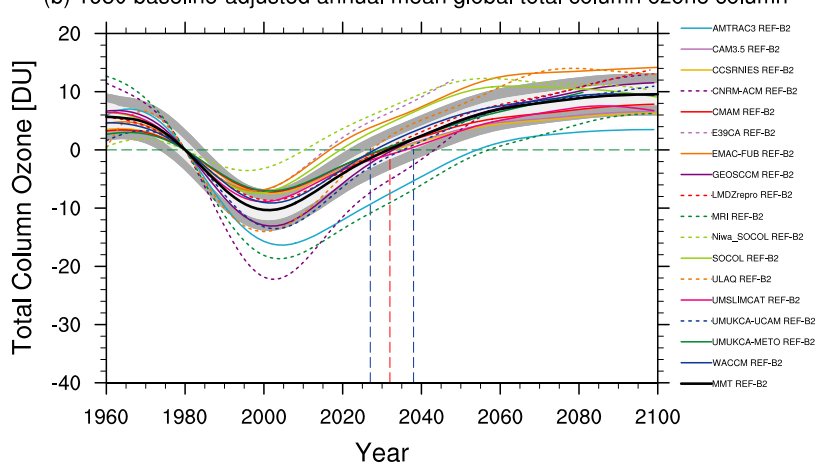

Fig. 1. (a) 1960 and (b) 1980 baseline-adjusted annual mean global total ozone column from the 17 reference simulations (REF-B2). The thick black line shows the multi-model mean and the light- and dark-grey shaded regions show the $95 \%$ confidence and $95 \%$ prediction intervals, respectively. The red vertical dashed line indicates the year when the multi-model mean returns to 1980 values and the blue vertical dashed lines indicate the uncertainty in these return dates. The green horizontal dashed line refers to the 1980 baseline, which may differ from zero when referenced to another year, e.g. 1960 as in panel (a).

induced stratospheric cooling, shown by the red to blue transition from 1960 to 2100 in the REF-B2 trace in Fig. 4a. The fixed ODS simulation shows ozone in the upper stratosphere slowly increasing with time under the influence of increasing $\mathrm{CO}_{2}$ and resultant stratospheric cooling. In contrast to the REF-B2 simulation, the fixed GHG simulation shows that the response of ozone to ESC through the 21st century is almost identical to that through the 20th century. In this simulation, because GHGs are fixed, temperature shows almost no trend from 1960 to 2100 (see also Fig. 3a). To test whether the perturbations to ozone from ODS and GHG changes are independent, the ozone changes due to the combined effect of ODSs and GHGs changes in REF-B2 are compared to the sum of the ozone changes due to only the effect of ODSs (fGHG) and due to only effects of GHGs (fODS). The comparison is then used to test whether these two effects on ozone are linearly additive, i.e. whether the effect of ODSs (or GHGs) on ozone depends on GHG (or
ODS) levels. The close agreement between the REF-B2 and grey traces in Fig. 4a indicates that the system is close to being linearly additive. The system deviates most from linear additivity in 2000 when the ozone depletion is largest. However, this deviation may result from the fODS simulation being forced by SSTs taken from a model simulation where the radiative forcing effects of transiently changing ODSs were included. As a result, even though the radiative effects of ODSs are kept fixed in the fODS simulation, their effects are felt to a lesser extent through the SSTs.

\subsubsection{Tropical lower stratospheric ozone}

In the tropical lower stratosphere, a robust feature simulated by all CCMs is that ozone in the REF-B2 simulations shows steadily declining values from 1960 to 2100 and ozone never returns to its 1980 value (Fig. 2b). The primary mechanism causing this trend is the increase in tropical upwelling through the 21st century, which is a robust result in CCM simulations (see Fig. 5 as well as Butchart et al. , 2006, 2010; Oman et al., 2010b; Chapter 4 of SPARC CCMVal, 2010). Tropical lower stratospheric ozone content is mostly determined by a balance between the rate of ozone production (i.e. from photolysis of $\mathrm{O}_{2}$ ) and the rate at which the air is transported through and out of the tropical lower stratosphere (Avallone and Prather, 1996). A faster transit of air through the tropical lower stratosphere from enhanced tropical upwelling leads to less time for production of ozone and hence to lower ozone levels in this region. The increase in tropical upwelling in fODS is similar to that in REF-B2 in all models and in the multi-model trend, confirming that changing halogens do not contribute to this trend which is caused by climate change and in particular climate-change induced SST changes. This is also evidenced by the increase in upwelling in a SOCOL fGHG simulation in which GHGs were fixed but SSTs evolved as in REF-B2 (not shown), in agreement with previous findings (Fomichev et al., 2007; Deckert and Dameris, 2008a, b; Oman et al., 2009). Correspondingly, the fGHG multi-model ozone trend in the tropical lower stratosphere $(50 \mathrm{hPa})$ stays nearly constant throughout the 21 st century, whereas the fODS multi-model ozone trend is very similar to that in REF-B2 and does not respond to ESC changes (red curve in Fig. 2b), indicating that this region is mainly controlled by changes in climate rather than ODSs.

This is a consistent result which is simulated by nearly all models (see Figs. S3 and S4). Only ULAQ has a higher sensitivity of ozone to halogens than all other models (see also Fig. 4 of Oman et al., 2010b) which could explain why in this simulation the suppressed tropical ozone, unlike in all other models, is mainly determined by halogen changes until 2030. This is concluded from the fact that ozone in the fGHG simulation in ULAQ is nearly identical to REF-B2 until 2030 (Fig. S4b). Only after 2030 does climate change dominate halogen sensitivity in ULAQ. One reason for this 
(a) Tropical Upper Stratosphere

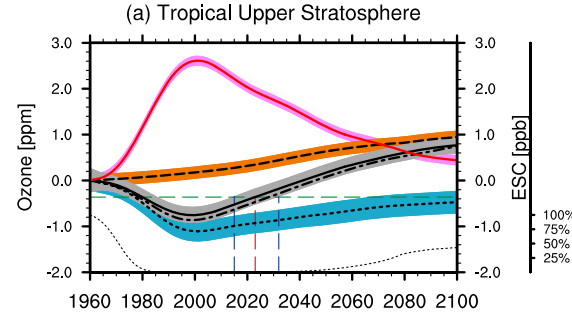

(c) NH midlatitudes Upper Stratosphere

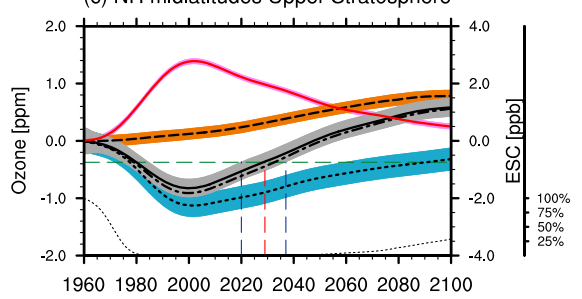

(e) $\mathrm{SH}$ midlatitudes Upper Stratosphere

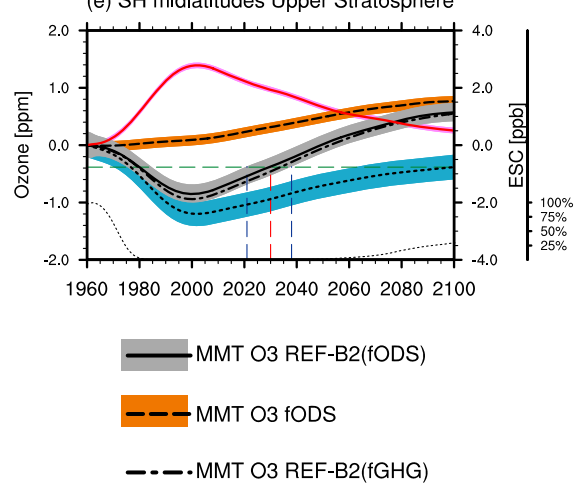

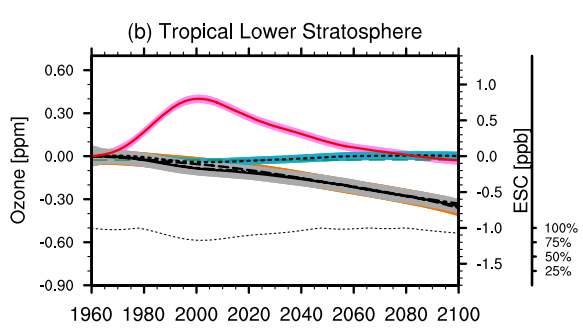

(d) $\mathrm{NH}$ midlatitudes Lower Stratosphere
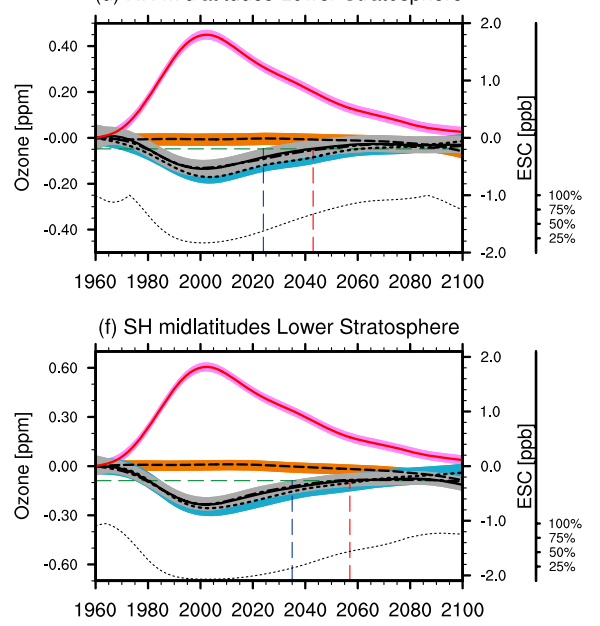

-...-MMT O3 fGHG

MMT ESC REF-B2(fODS)

Fig. 2. Extra-polar, annual mean 1960 baseline-adjusted ozone projections and 95\% confidence interval for the multi-model trend (MMT) of REF-B2 which is derived from the models that performed the fODS simulation (MMT O3 REF-B2(fODS); black line and grey shaded area) and from the models that performed the fGHG simulation (MMT O3 REF-B2(fGHG); black dashed-dotted line). Also shown is the multi-model trend plus $95 \%$ confidence interval for fODS (black dotted line and orange shaded area), fGHG (black dashed line and blue shaded area), and ESC (MMT ESC REF-B2(fODS) displayed with red solid line and light red shaded area). The different panels show (a) $5 \mathrm{hPa}$ and (b) $50 \mathrm{hPa}$ tropics $\left(25^{\circ} \mathrm{S}-25^{\circ} \mathrm{N}\right)$, (c) $5 \mathrm{hPa}$ and (d) $50 \mathrm{hPa}$ northern midlatitudes $\left(35^{\circ} \mathrm{N}-60^{\circ} \mathrm{N}\right)$, (e) $5 \mathrm{hPa}$ and (f) $50 \mathrm{hPa}$ southern midlatitudes $\left(35^{\circ} \mathrm{S}-60^{\circ} \mathrm{S}\right)$. The multi-model mean for REF-B2, fODS, and ESC is formed from 9 CCMs (CCSRNIES, CMAM, GEOSCCM, LMDZrepro, MRI, SOCOL, UMSLIMCAT, ULAQ, and WACCM) and the one for FGHG from 7 CCMs (CCSRNIES, CMAM, EMAC-FUB, E39CA, MRI, ULAQ, and WACCM). The red vertical dashed line indicates the year when the multi-model mean of the 9 CCMs in REF-B2 returns to 1980 values (green horizontal dashed line) and the blue vertical dashed lines indicate the uncertainty in these return dates. The thin dotted black line in the bottom of each panel shows the results of the t-test's confidence level that the multi-model means from fODS and REF-B2 are from the same population (see Sect. 5 for details). The individual models are shown in figures in the supplementary material. Note the differing Y-axis scales.

could be the coarse horizontal resolution in ULAQ or that the model includes an explicit code for NAT and ice particle formation, growth and transport which can form not only in the winter polar regions but also in the tropical UTLS. In addition, ULAQ includes a parameterization for upper tropospheric cirrus ice particles (Kärcher and Lohmann, 2002). Decreases in ozone in the lower stratosphere and total column ozone in the 2 nd half of the 21 st century in the REFB2 simulations of SOCOL are significantly larger than in all other simulations (Figs. S3b and S12b) due to a particularly large Brewer-Dobson circulation strength and trend (Oman et al., 2010b). For total column ozone this is similar in the other
ECHAM5 based models (EMAC-FUB and NIWA-SOCOL, see Fig. S1b).

An attribution of ozone changes in the tropical lower stratosphere to changes in ODSs and GHGs is shown in Fig. 4b. In this panel the multi-model mean was calculated using the CCSRNIES, CMAM, MRI and WACCM models (see individual models in Figs. S14 to S18 in the supplementary material). ULAQ was also excluded for the reasons outlined above (see also supplementary online material). In the lower stratosphere in the tropics ozone shows little response to ESC through the 20th and 21st centuries as seen from the fGHG trace. The $\sim 25 \%$ decrease in ozone from 
(a) Tropical Upper Stratosphere

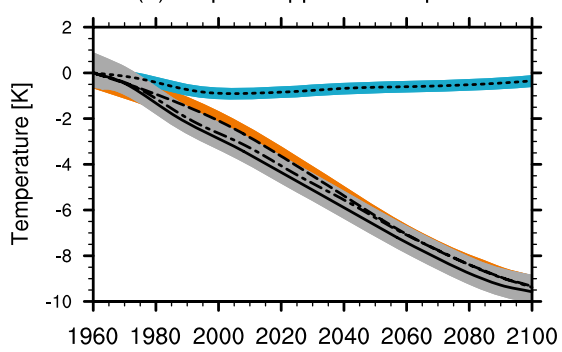

(c) NH midlatitudes Upper Stratosphere

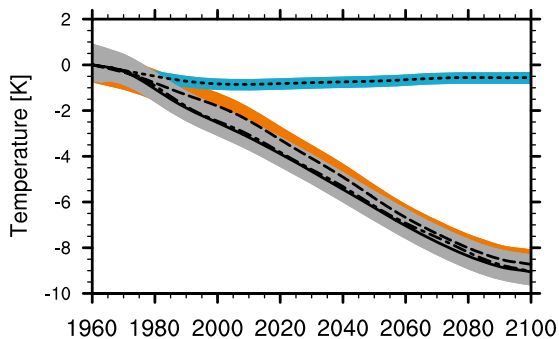

(e) SH midlatitudes Upper Stratosphere

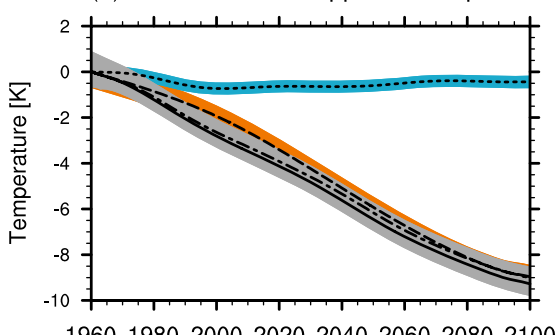

MMT REF-B2 (fODS)

- MMT fODS

--- MMT REF-B2 (fGHG) (b) Tropical Lower Stratosphere

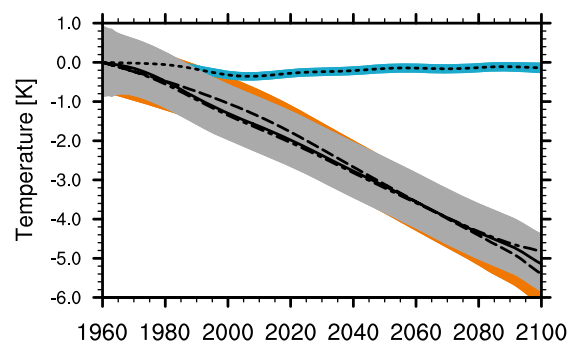

(d) $\mathrm{NH}$ midlatitudes Lower Stratosphere

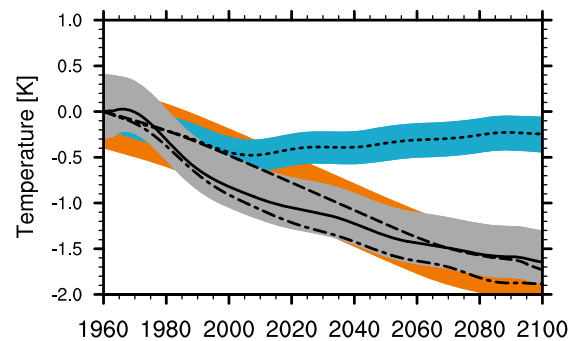

(f) SH midlatitudes Lower Stratosphere

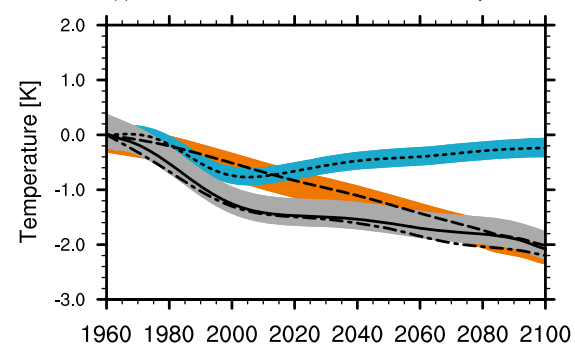

-...-MMT $\mathrm{AGHG}$

Fig. 3. Same as Fig. 2, but for temperature.

1960 to 2100 in the reference scenario results from GHGinduced changes to stratospheric dynamics as evidenced by the fixed ODS scenario. Note also that in the fODS simulation ESC decreases with time in response to these circulation changes. As in the upper stratosphere, the response of ozone to ODSs and GHGs is almost linearly additive as shown by the close agreement between the REF-B2 and grey traces in Fig. 4b. This indicates that ozone in the tropical lower stratosphere responds primarily to the underlying SSTs with only a small contribution from the in situ effects of GHG radiative forcing.

\subsubsection{Tropical total column ozone}

The evolution of tropical column ozone (Fig. 6b) depends on the balance between the increase in upper stratospheric concentrations and the decrease in lower stratospheric con- centrations, and as a result the projected changes are in general small compared to extra-tropical regions in the REF-B2 simulation ( $\sim 7 \mathrm{DU}$, see Table 4$)$. In the MMT calculated from the 17 CCMs' reference simulations, there is a general decline from the start of the integrations until the turn of the century, followed by a gradual increase until about 2050 with $70 \%$ of the simulated ozone lost since 1980 recovered by 2025 and $110 \%$ by 2050 in the multi-model mean (Table 4). After 2050, column ozone amounts decline slightly again toward the end of the century. Increased tropical upwelling is one of the largest drivers of this (see Fig. 5 as well as Shepherd, 2008 and Li et al., 2009). This is also confirmed by the similarity of the REF-B2 and fODS simulations in Fig. 6b after 2050. In the fGHG simulation, upper stratospheric tropical ozone is consistently lower than in REF-B2 (Fig. 2a) while tropical upwelling is not increasing (Fig. 5), and lower stratospheric tropical ozone is higher than 

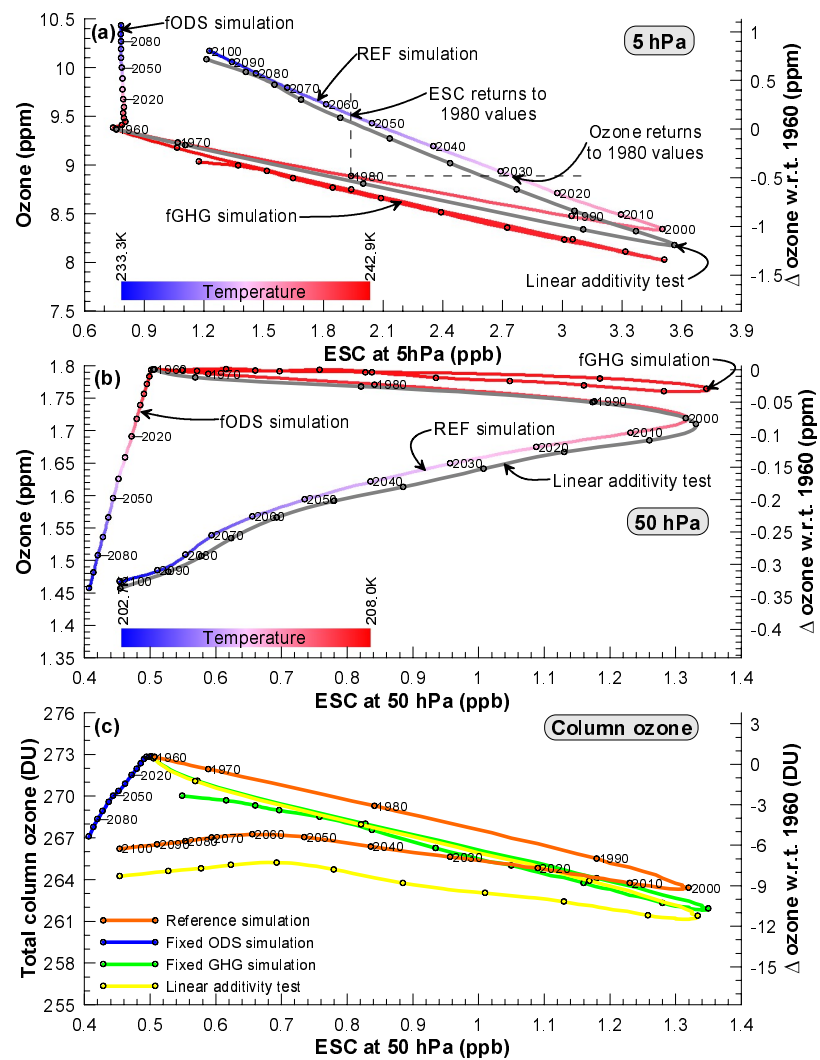

Fig. 4. (a) Annual multi-model mean tropical ozone as a function of $\mathrm{ESC}=\mathrm{Cl}_{\mathrm{y}}+5 \times \mathrm{Br}_{\mathrm{y}}$ at $5 \mathrm{hPa}$ and averaged between $25^{\circ} \mathrm{S}$ and $25^{\circ} \mathrm{N}$. (b) as in panel (a) but at $50 \mathrm{hPa}$ and where $\mathrm{ESC}=\mathrm{Cl}_{\mathrm{y}}+60 \times \mathrm{Br}_{\mathrm{y}}$. In panels (a) and (b) the REF-B2, fODS, and fGHG simulations are shown using traces colored according to the multi-model-mean temperature using the scale shown in the bottom left of each panel. The grey traces in these two panels show the additive effects of the fODS and fGHG simulations calculated from: $\operatorname{Grey}_{\mathrm{ESC}}(t)=\mathrm{fGHG}_{\mathrm{ESC}}(t)+\operatorname{fODS}_{\mathrm{ESC}}(t)-\operatorname{fODS}_{\mathrm{ESC}}(1960)$ and $\operatorname{Grey}_{\text {ozone }}(t)=\mathrm{fGHG}_{\text {ozone }}(t)+\mathrm{fODS}_{\text {ozone }}(t)-\mathrm{fODS}_{\text {ozone }}$ (1960). Differences between the grey and REF-B2 traces indicate a lack of linear additivity in the system. Panel (c), as in (b) but for total column ozone and without color coding by temperature. In this panel the fODS+fGHG trace is shown in yellow (yellow=blue+green). In all three panels, on each trace, reference years are shown every 10th data point with year labels shown for the REF-B2 simulation. The multi-model means displayed in this figure were derived from a subset of the 5 models that provided both fGHG and fODS simulations (see text for details).

in REF-B2 and remains nearly constant in the fGHG simulation (Fig. 2b). Consistently, the MMT of tropical column ozone in fGHG is higher than REF-B2 at the end of the 21st century and returns to its 1980 values around 2060 (Fig. 6b).

A comparison of the REF-B2, fODS and fGHG simulations for tropical total column ozone is also shown, using a different format, in Fig. 4c with the multi-model mean calculated from CCSRNIES, CMAM, MRI, and WACCM. In-

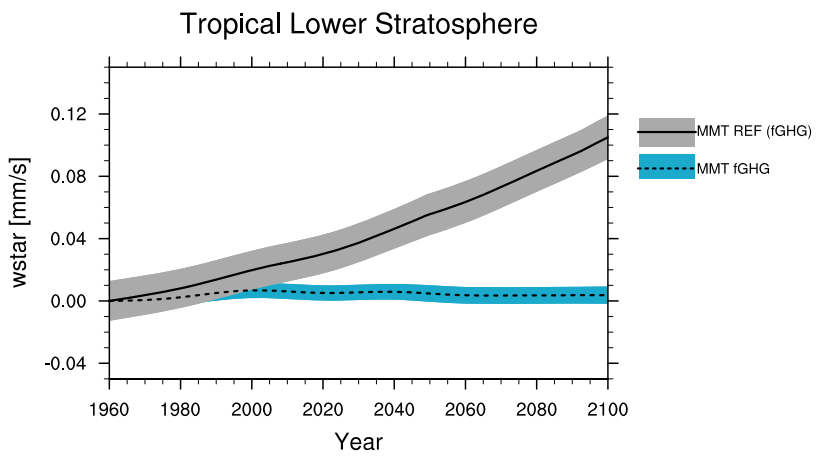

Fig. 5. Multi-model mean and $95 \%$ confidence interval of the 1960 baseline-adjusted annual mean $\mathrm{w}^{*}$ between $20^{\circ} \mathrm{S}$ and $20^{\circ} \mathrm{N}$ at $70 \mathrm{hPa}$ for REF-B2 (solid black line and grey shaded area) and fGHG (black dashed line and blue shaded area). The individual models are shown in the supplementary material in Fig. S11.

terestingly, unlike ozone at 5 and $50 \mathrm{hPa}$ in the tropics, total column ozone shows deviations away from linear additivity demonstrated by the lack of coincidence of the orange and yellow traces in Fig. 4c. While the exact causes of such deviations in linear additivity are not yet known, it is possible that the inclusion of the effects of ODS radiative forcing via the SSTs used as boundary conditions in the fODS simulation may be a contributing factor.

\subsection{Midlatitude ozone}

\subsubsection{Midlatitude upper stratospheric ozone}

In the midlatitude upper stratosphere, which is mainly photochemically controlled, ozone increases due to $\mathrm{CO}_{2}$-induced cooling of the stratosphere that slows chemical destruction rates. Increases in $\mathrm{N}_{2} \mathrm{O}$ and $\mathrm{CH}_{4}$ appear to play a minor role in upper stratospheric ozone depletion under the SRES A1B GHG scenario (Eyring et al., 2007, 2010; Oman et al., 2010a).

Overall, the projected evolution of midlatitude upper stratospheric ozone is very similar to that in the tropics. In the SRES A1B GHG scenario the ozone evolution is characterized by increases throughout the 21 st century (Fig. 2c, e) due to $\mathrm{CO}_{2}$-induced cooling (Fig. 3c, e).

\subsubsection{Midlatitude lower stratospheric ozone}

In the lower stratosphere the evolution of midlatitude ozone differs from that in the tropics (compare panel b in Fig. 2 with panels $d$ and $f$ ), and rather than a steady decrease in ozone, first a decrease is simulated between 1960 and 2000, which is then followed by a steady increase throughout the 21 st century. As in the tropics, changes in transport also play a role in the ozone evolution in midlatitudes but here the increase in the meridional circulation is more likely to lead to an increase rather than a decrease in ozone. Inter-hemispheric 
(a) Global annual mean

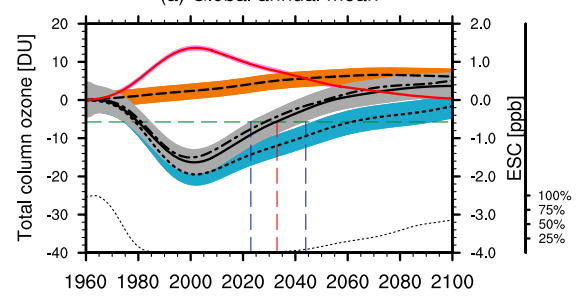

(c) $\mathrm{NH}$ midlatitudes annual mean

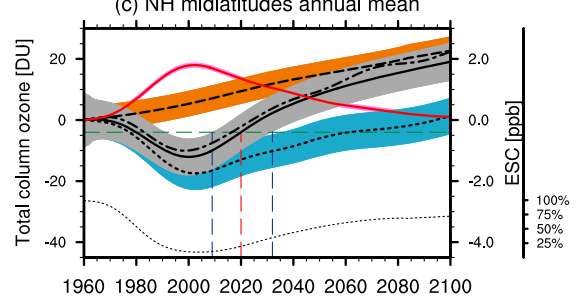

(e) Arctic March mean

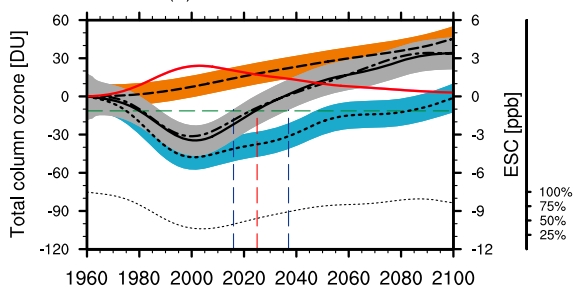

- MMT Toz REF-B2 (fODS)

- MMT Toz fODS (b) Tropics annual mean
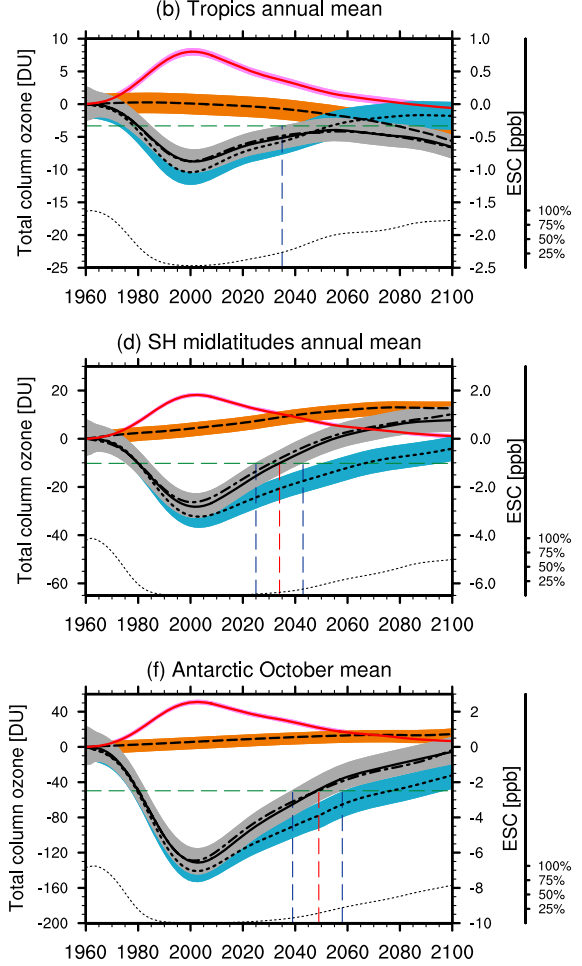

-...MMT Toz fGHG

MMT ESC REF-B2 (fODS)

- - MMT Toz REF-B2 (fGHG)

Fig. 6. 1960 baseline-adjusted total column ozone projections and $95 \%$ confidence interval for the multi-model REF-B2 trend which is in the one case derived from the models that performed the fODS simulation (MMT O3 REF-B2(fODS); black line and grey shaded area) and in the other case from the models that performed the fGHG simulation (MMT O3 REF-B2(fGHG); black dashed-dotted line). Also shown is the multi-model trend plus 95\% confidence interval for fODS (black dotted line and orange shaded area), fGHG (black dashed line and blue shaded area), and ESC (MMT ESC REF-B2(fODS; red solid line and light red shaded area). The different panels show (a) global $\left(90^{\circ} \mathrm{S}-90^{\circ} \mathrm{N}\right.$ annual mean), (b) tropics $\left(25^{\circ} \mathrm{S}-25^{\circ} \mathrm{N}\right.$ annual mean), (c) $\mathrm{NH}$ midlatitudes $\left(35^{\circ} \mathrm{N}-60^{\circ} \mathrm{N}\right.$ annual mean), (d) $\mathrm{SH}$ midlatitudes $\left(35^{\circ} \mathrm{S}-60^{\circ} \mathrm{S}\right.$ annual mean), (e) Arctic $\left(60^{\circ} \mathrm{N}-90^{\circ} \mathrm{N}\right.$ March mean), and (f) Antarctic $\left(60^{\circ} \mathrm{S}-90^{\circ} \mathrm{S}\right.$ October mean). The red vertical dashed line indicates the year when the multi-model mean in REF-B2 returns to 1980 values (green horizontal dashed line) and the blue vertical dashed lines indicate the uncertainty in these return dates. The thin dotted black line shows the results of the t-test's confidence level that the multi-model means from fODS and REF-B2 are from the same population (see Sect. 5 for details). The individual models are shown in the supplementary material. Note the differing Y-axis scales.

differences in changes in transport could explain the hemispheric difference in ozone evolution, since the increase in stratospheric circulation transports more ozone into the northern midlatitudes lower stratosphere than into the $\mathrm{SH}$ (Shepherd, 2008; Li et al., 2009) and since in the SH the mixing of ozone poor air from the ozone hole into midlatitudes could also contribute. Effects of inclusion of ozone depleted over Antarctica, resulting from excursions of the Antarctic polar vortex away from the pole, in the calculation of the southern midlatitude $\left(60^{\circ} \mathrm{S}-35^{\circ} \mathrm{S}\right)$ mean ozone likely also contribute to the hemispheric differences in ozone evolution.
Differences between the ozone evolution in the fGHG and REF-B2 simulations in the midlatitude lower stratosphere are generally small in both hemispheres (Fig. 2d, f), indicating that changes in GHG do not play a large role in this region. However, due to changes in transport discussed above, in REF-B2 ozone in the lower stratosphere returns to 1980 levels around 15 years earlier in the northern than in the southern midlatitudes. The temperature evolution in the midlatitude lower stratosphere is similar to that in the tropics (compare panel $b$ in Fig. 3 with panels $d$ and $f$ ), though the temperature responds more to changes in ODSs through ODS induced changes in ozone (concluded by the larger difference of fODS and REF-B2 in the midlatitudes), in particular 
in the southern midlatitudes, consistent with previous studies (WMO, 2007; Shepherd and Jonsson, 2008).

\subsubsection{Midlatitude total column ozone}

Because ozone averaged over midlatitudes first decreases until around 2000 and then increases again in the upper and lower stratosphere over the 21 st century, a similar evolution is projected for midlatitude total column ozone (Fig. 6c, d). In both hemispheres the 1960 baseline-adjusted midlatitude multi-model mean ozone indicates that the ozone minimum is reached by $\sim 2000$ followed by a steady and significant increase. By 2025, Northern (Southern) Hemisphere column ozone is projected to have regained $130 \%$ (70\%) of the amount lost between 1980 and 2000 (2002) with 230\% (145\%) of the loss regained by 2050 (see Table 4). By 2050, midlatitude total column ozone in both hemispheres is projected to be above 1980 levels, but the return to historical values in the northern midlatitudes is more advanced than in the southern midlatitudes, caused by differences in return dates in the lower stratosphere (see Fig. 2d, f), probably because of strengthened transport. By 2100, the column ozone in the northern (southern) midlatitudes is projected to have increased by 22 (19) DU compared to 1980 amounts. Other influences such as $\mathrm{NO}_{\mathrm{x}}$ and $\mathrm{HO}_{\mathrm{x}}$ catalysed ozone destruction have small impacts because the source molecules $\left(\mathrm{N}_{2} \mathrm{O}\right.$ and $\mathrm{H}_{2} \mathrm{O}$ ) have small trends in the reference simulation which is based on the SRES A1B GHG scenario (Chapter 6 of SPARC CCMVal, 2010; Oman et al., 2010a). This is different in other GHG scenarios (see further discussion in Oman et al., 2010a and Eyring et al., 2010). In both hemispheres the total column ozone MMT in the fGHG simulation is lower than in REF-B2 (Fig. 6c, d) due to differences between these simulations mainly in the upper stratosphere (Fig. 2c, e) where the GHG-induced effect on ozone is $\sim 10$ times larger than in the lower stratosphere, where differences are very small.

An attribution of total column ozone changes in the northern and southern midlatitudes to changes in ODSs and GHGs is shown in panels (b) and (c) of Fig. 7 with the multimodel mean calculated from all the $5 \mathrm{CCMs}$ that performed both simulations (CCSRNIES, CMAM, MRI, ULAQ, and WACCM). The REF-B2 simulation shows that total column ozone decreases from 1960 to 2000 but at a greater rate over southern midlatitudes than over northern midlatitudes; over northern midlatitudes ozone shows a $-7 \mathrm{DU} / \mathrm{ppb}$ sensitivity to ESC over the 1960 to 2000 period while over southern midlatitudes the sensitivity is $-16 \mathrm{DU} / \mathrm{ppb}$. This greater than a factor of two difference in sensitivity of southern midlatitude ozone to ESC, and the slightly greater levels of ESC reached over southern midlatitudes, results in a 3.6\% total column ozone reduction over northern midlatitudes from 1960 to 2000 and an $7.7 \%$ total column ozone reduction over southern midlatitudes over this period. In both hemispheres, as ESC decreases, total column ozone does not simply retrace the 1960-2000 path, but shows systematically elevated

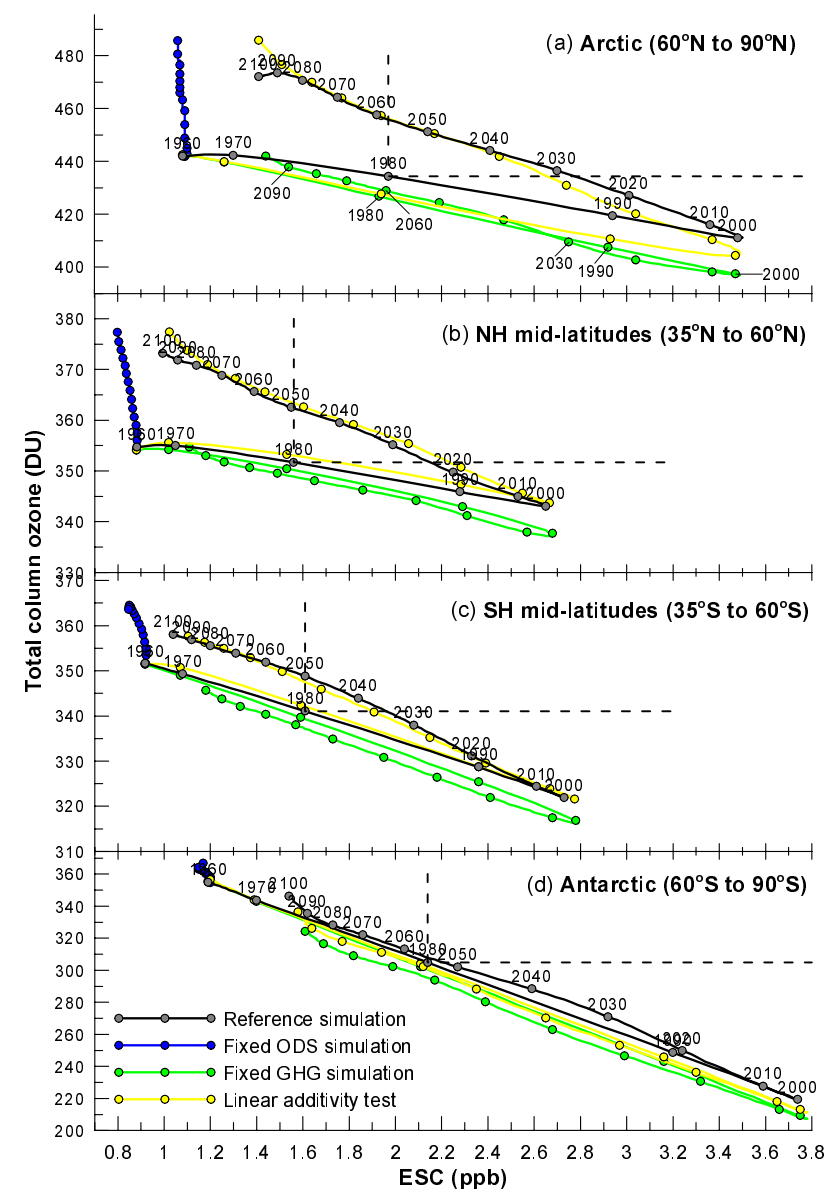

Fig. 7. As in Fig. 4, but for total column ozone in the midlatitudes (annual average) and polar regions (March mean in Arctic and October mean in Antarctic). The multi-model mean is calculated from all models that performed both fODS and fGHG simulations in addition to REF-B2 i.e. CCSRNIES, CMAM, MRI, ULAQ and WACCM. ESC is shown for $50 \mathrm{hPa}$. Blue traces show results from simulations where prescribed ODSs are fixed at 1960 values (fODSs). Green traces show results from simulations where prescribed GHGs are fixed at 1960 values (fGHG). Yellow traces show the additive effects of the fODS and fGHG simulations calculated from: Yellow $\operatorname{ESC}(t)=\operatorname{fGHGESC}(t)+\operatorname{fODSESC}(t)$ - fODSESC(1960) and Yellow Ozone $(t)=$ fGHGozone $(t)+$ fODSozone $(t)$ - fODSozone (1960). Differences between the yellow and REF-B2 traces indicate a lack of linear additivity in the system.

ozone through the 21 st century. As a result, over northern midlatitudes total column ozone returns to 1980 values in the early 2020s, well before ESC returns to its 1980 value in the late 2040s. Similarly, over southern midlatitudes total column ozone returns to 1980 values in the mid-2030s (a decade later than in the Northern Hemisphere), and well before ESC returns to its 1980 value in the late 2040s. It is clear from the fODS scenario (blue traces in Fig. 7), that the elevated ozone through the 21 st century results from GHG-induced 
Table 4. Summary of the extent to which ozone has returned to 1960 and 1980 levels from its absolute minimum, expressed as percentages calculated from the 1980 baseline-adjusted timeseries of all 17 CCMs' reference simulations. 0\% denotes that ozone has not increased above the minimum, $50 \%$ denotes that ozone at this date is halfway between the minimum observed and the 1960 or 1980 level, $100 \%$ denotes that ozone has returned to the 1960 or 1980 level, and >100\% denotes that ozone exceeds the 1960 or 1980 level at this date.

\begin{tabular}{|c|c|c|c|c|c|c|c|c|c|c|}
\hline \multirow{2}{*}{$\begin{array}{l}\text { Region } \\
\text { Unit }\end{array}$} & \multirow{2}{*}{$\begin{array}{l}\text { Reference } \\
\text { Year; in } \\
\text { brackets } \\
\text { DU } \\
\text { (a) }\end{array}$} & \multirow{2}{*}{$\begin{array}{l}\text { Year when } \\
\text { minimum oc- } \\
\text { curs; in } \\
\text { brackets DU } \\
\text { (a) }\end{array}$} & \multicolumn{2}{|c|}{$\begin{array}{l}\text { Difference to } \\
\text { reference year } \\
\text { in } 2025\end{array}$} & \multicolumn{2}{|c|}{$\begin{array}{l}\text { Difference to } \\
\text { reference year } \\
\text { in } 2050\end{array}$} & \multicolumn{2}{|c|}{$\begin{array}{l}\text { Difference to } \\
\text { reference year } \\
\text { in } 2075\end{array}$} & \multicolumn{2}{|c|}{$\begin{array}{l}\text { Difference to } \\
\text { reference year } \\
\text { in } 2100\end{array}$} \\
\hline & & & (DU) & $(\%)$ & (DU) & $(\%)$ & (DU) & $(\%)$ & (DU) & $(\%)$ \\
\hline \multirow[t]{2}{*}{$\begin{array}{l}\text { Global an- } \\
\text { nual mean }\end{array}$} & $\begin{array}{l}1960 \\
(312 \mathrm{DU})\end{array}$ & $\begin{array}{l}2001 \\
(296 \mathrm{DU})\end{array}$ & -8 & $50 \%$ & -1 & $95 \%$ & 3 & $115 \%$ & 4 & $125 \%$ \\
\hline & $\begin{array}{l}1980 \\
(306 \mathrm{DU})\end{array}$ & & -2 & $80 \%$ & 5 & $150 \%$ & 8 & $180 \%$ & 10 & $190 \%$ \\
\hline \multirow[t]{2}{*}{$\begin{array}{l}\text { Tropics an- } \\
\text { nual mean }\end{array}$} & $\begin{array}{l}1960 \\
(272 \mathrm{DU})\end{array}$ & $\begin{array}{l}2000 \\
(265 \mathrm{DU})\end{array}$ & -4 & $45 \%$ & -2 & $70 \%$ & -3 & $60 \%$ & -6 & $25 \%$ \\
\hline & $\begin{array}{l}1980 \\
(270 \mathrm{DU})\end{array}$ & & -1 & $70 \%$ & 0 & $110 \%$ & -1 & $90 \%$ & -3 & $40 \%$ \\
\hline \multirow{2}{*}{$\begin{array}{l}\text { Northern } \\
\text { midlatitude } \\
\text { annual } \\
\text { mean }\end{array}$} & $\begin{array}{l}1960 \\
(357 \mathrm{DU})\end{array}$ & $\begin{array}{l}2000 \\
(344 \mathrm{DU})\end{array}$ & -2 & $85 \%$ & 7 & $155 \%$ & 14 & $205 \%$ & 18 & $240 \%$ \\
\hline & $\begin{array}{l}1980 \\
\text { (353 DU) }\end{array}$ & & 3 & $130 \%$ & 11 & $230 \%$ & 18 & $300 \%$ & 22 & $355 \%$ \\
\hline \multirow{2}{*}{$\begin{array}{l}\text { Southern } \\
\text { midlatitude } \\
\text { annual } \\
\text { mean }\end{array}$} & $\begin{array}{l}1960 \\
\text { (349 DU) }\end{array}$ & $\begin{array}{l}2002 \\
(322 \mathrm{DU})\end{array}$ & -15 & $45 \%$ & -2 & $90 \%$ & 6 & $120 \%$ & 9 & $130 \%$ \\
\hline & $\begin{array}{l}1980 \\
\text { (339 DU) }\end{array}$ & & -5 & $70 \%$ & 7 & $145 \%$ & 16 & $190 \%$ & 19 & $210 \%$ \\
\hline \multirow{2}{*}{$\begin{array}{l}\text { Antarctic } \\
\text { October } \\
\text { mean }\end{array}$} & $\begin{array}{l}1960 \\
(374 \mathrm{DU})\end{array}$ & $\begin{array}{l}2003 \\
(244 \mathrm{DU})\end{array}$ & -95 & $30 \%$ & -53 & $60 \%$ & -26 & $80 \%$ & -9 & $95 \%$ \\
\hline & $\begin{array}{l}1980 \\
\text { (322 DU) }\end{array}$ & & -42 & $45 \%$ & -1 & $100 \%$ & 25 & $130 \%$ & 43 & $155 \%$ \\
\hline \multirow{2}{*}{$\begin{array}{l}\text { Arctic } \\
\text { March } \\
\text { mean }\end{array}$} & $\begin{array}{l}1960 \\
(459 \mathrm{DU}\end{array}$ & $\begin{array}{l}2002 \\
\text { (422 DU) }\end{array}$ & -15 & $60 \%$ & 6 & $115 \%$ & 22 & $160 \%$ & 33 & $190 \%$ \\
\hline & $\begin{array}{l}1980 \\
(445 \mathrm{DU})\end{array}$ & & -1 & $95 \%$ & 20 & $185 \%$ & 36 & $255 \%$ & 46 & $300 \%$ \\
\hline
\end{tabular}

stratospheric cooling and changes in circulation. The fODS simulation also shows ESC decreasing with time even though ODSs are fixed at 1960 values. This results from the increasing strength of the Brewer-Dobson circulation through the 21 st century and a resultant decrease in the time available to photolyze ODSs in the upper stratosphere and mesosphere. It is also clear from the REF-B2 and fODS traces in Fig. 7 that by 2100 total column ozone over midlatitudes is still being influenced by ESC. In both the northern and southern midlatitudes the effects of ODSs and GHGs on column ozone are approximately linearly additive (agreement of black and yellow traces in Fig. $7 b$ and c). 

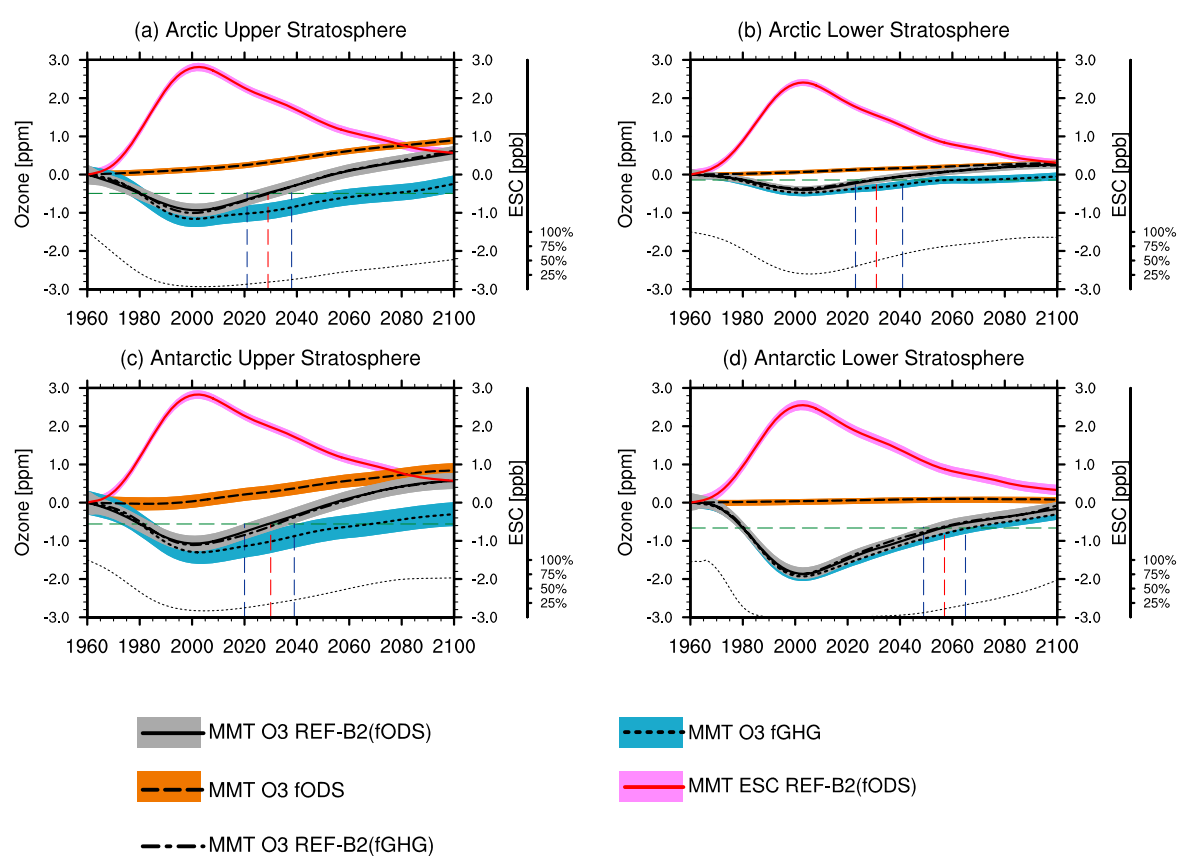

Fig. 8. Same as Fig. 2, but ozone in polar regions in the Arctic (March mean, upper row) and in the Antarctic (October mean, lower row). The upper stratosphere is shown for the $5 \mathrm{hPa}$ level and the lower stratosphere for the $50 \mathrm{hPa}$ level.

\subsection{Polar ozone in spring}

\subsubsection{Antartic spring-time ozone}

In the Antarctic $\left(60^{\circ}-90^{\circ} \mathrm{S}\right)$ in spring, the general characteristics of the ozone evolution in the CCMVal-2 reference simulations are similar in all CCMs and similar to the CCM projections shown in Eyring et al. (2007). Lower stratospheric ozone (Fig. 8d) and total column ozone (Fig. 6f) are dominated by responses to ODSs, resulting in peak ozone depletion around $2000(\sim 80 \mathrm{DU}$ lower than its 1980 value, see Table 4), followed by a slow and steady increase until 2100 . By the year 2025, 45\% of the ozone loss since 1980 is projected to rebuild, and $100 \%$ by 2050 . By the end of the 21 st century, Antarctic spring ozone will have higher concentrations than in 1980 (+43 DU, 155\%), but still be lower than in 1960 (-9 DU, 95\%). The dominant role of ODSs in affecting Antarctic spring ozone is well known (Eyring et al., 2007; Chapter 9 of SPARC CCMVal, 2010) and is further confirmed here by the large difference between the fODS simulation and the REF-B2 simulation (Figs. 8d and 6f) compared to the relatively small difference between the REF-B2 and the fGHG simulations. However, climate change also plays a role in the Antarctic, and while the multi-model total column ozone trend estimate for the fGHG simulation returns to 1980 values around the time when ESC does (compare dotted black line and red line in Fig. 6f), the MMT of REF-B2 returns earlier to 1980 levels by around 10 years (2045-2060) resulting primarily from upper stratospheric cooling (Fig. 9c) and resultant increases in ozone (Fig. 8c).
Attribution of Antarctic column ozone changes to ODSs and GHGs is shown in Fig. 7d with the multi-model mean calculated as for midlatitude total column ozone (see individual models in Figs. S34 to S38 in the supplementary material). The reference simulation shows total column ozone decreasing from 1960 to 2000 with a 52 DU/ppb sensitivity to ESC, leading to a $35 \%$ decrease in total column ozone over this period. Unlike the midlatitudes and Arctic (Fig. 7a-c), the total column ozone evolution over Antarctica (Fig. 7d) shows small sensitivity to changes in GHGs with the return path (21st century) closely tracking the outbound path (20th century). Since ozone shows only small response to GHGs in this region, assessing the additivity of the simulations is not appropriate.

\subsubsection{Arctic spring-time ozone}

In the Arctic $\left(60^{\circ}-90^{\circ} \mathrm{N}\right)$ in spring, lower stratospheric ozone (Fig. 8b) and total column ozone (Fig. 6e) follow a similar evolution to spring-time Antarctic ozone, but with smaller ozone losses during the peak ozone depletion period ( $\sim 23$ DU smaller than its 1980 value, see Table 4) and with ozone increasing significantly above 1980 and even 1960 values at the end of the century in the reference simulation. Most of the simulations using the fixed ODS scenarios show a steady increase in Arctic ozone over the 21st century, likely related to the increases in the strength of the BrewerDobson circulation and enhanced stratospheric cooling associated with increases in $\mathrm{CO}_{2}$. In the fixed GHG simulation, depletion of ozone in the Arctic is much larger than in 
(a) Arctic Upper Stratosphere

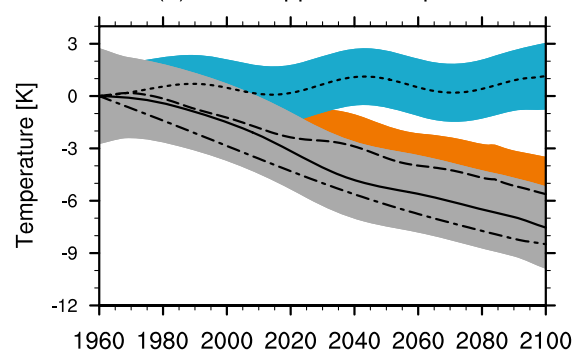

(c) Antarctic Upper Stratosphere

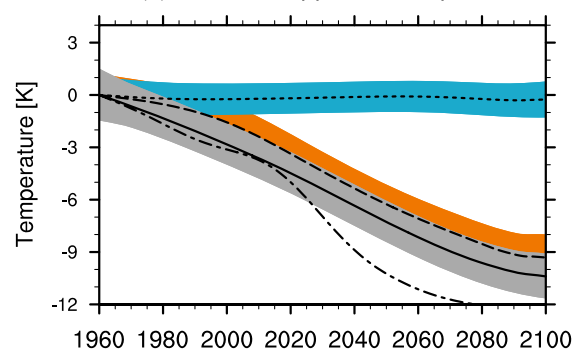

-MMT REF-B2 (fODS)

--- MMT fODS

----MMT REF-B2 (fGHG)

Fig. 9. Same as Fig. 8, but for temperature.

REF-B2 (Fig. 6e), with a much later date of return of ozone column amounts to 1980 values when the counterbalancing effects of GHGs are excluded.

The attribution of Arctic ozone changes to GHG and ODS changes is further illustrated in Fig. 7a, where an attribution of total column ozone changes over the Arctic to changes in ODSs and GHGs is shown for the multi-model mean calculated as for midlatitude total column ozone (see individual models in Figs. S29 to S33 in the supplementary material). The reference simulation shows total column ozone decreasing from 1960 to 2000 with a $-14 \mathrm{DU} / \mathrm{ppb}$ sensitivity to ESC, less than the $-16 \mathrm{DU} / \mathrm{ppb}$ sensitivity observed over southern midlatitudes. The increase in ESC from $1.1 \mathrm{ppb}$ in 1960 to $3.5 \mathrm{ppb}$ in 2000 leads to a $8.0 \%$ decrease in total column ozone over this period. As for the midlatitudes, total column ozone over the Arctic is elevated above what would be expected from changes in ESC by stratospheric cooling and changes to the Brewer-Dobson circulation induced by increasing GHGs - see fixed ODS simulation. Through the latter half of the century the system shows a high degree of linear additivity (close agreement of black and yellow traces in Fig. 7a). As discussed in Butchart et al. (2010) and Chapter 4 of SPARC CCMVal (2010), in the models the extra radiative cooling from growing amounts of GHGs is approximately balanced by a concomitant increase in the adiabatic (b) Arctic Lower Stratosphere

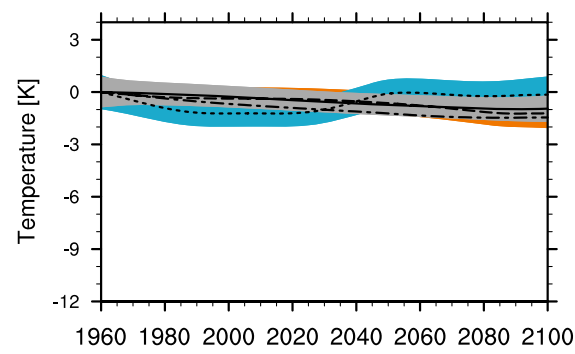

(d) Antarctic Lower Stratosphere

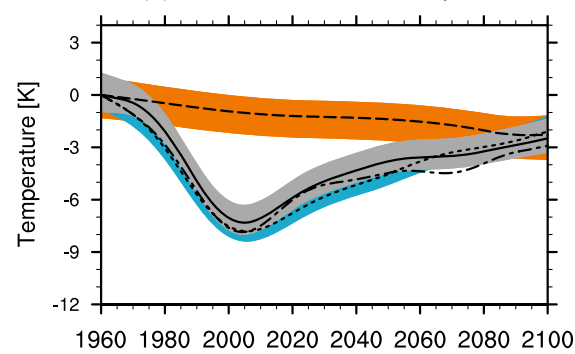

-...-MMT fGHG warming through increased polar downwelling with the net effect being a near zero temperature trend in the Arctic winter lower stratosphere. A small trend $(-1 \mathrm{~K}$ from 2000 to $2100)$ is simulated in the extended set of CCMVal-2 models in March (Fig. 9b). However, it is also important to note that there is a very large spread between the fODS simulations, with some models simulating a slight increase in temperature in the Arctic by 2100 (Fig. S10 in supplementary material). The large spread in the impact of GHG changes on Arctic temperature is likely to be related to changes in dynamical heating of the Arctic linked to GHG changes. Previous studies using stratospheric climate models have shown that the response to GHG changes can be very different between models with different horizontal resolution (Bell et al., 2010) and that these changes are related to changes in Arctic dynamical heating. The impact of ozone depletion and recovery on Arctic temperatures can be diagnosed from the fGHG runs in Fig. 9a. Arctic temperatures are close to their 1960 values by 2100 in this simulation and the temperatures from fODS and fGHG appear to be additive.

\section{Ozone return dates and full ozone recovery}

Two distinct milestones in the future evolution of ozone, namely the return of ozone to historical values and the full 
recovery of ozone from the effects of ODSs (WMO, 2007) are assessed and compared in the reference simulations (see also Introduction). Ozone return dates to 1980 values are derived from the 1960 and 1980 baseline-adjusted reference simulation (REF-B2) ozone time series. The selection of baseline adjustment has little effect on 1980 return dates and the uncertainty on that date increases by at most 3 years when shifting from 1980 to 1960 baseline adjusted time series (see Figs. 1, S1 and S2 for illustration as well as Table 3). The robustness of the 1980 return date to baseline adjustment selection means that 1980 ozone return dates calculated from the 1980 baseline-adjusted time series can be directly compared to the date of full ozone recovery which must be calculated from the 1960 baseline-adjusted time series. This is necessary because full recovery of ozone from the effects of ODSs is evaluated as when ozone is no longer significantly affected by ODSs (WMO, 2007), i.e. as the fODS and REFB2 simulations converge.

Here, we apply the student's t-test to test whether the multi-model means calculated from the fODS and REF-B2 simulations are from the same population, and use this to quantify the likelihood that full recovery has occurred. The sample variance $\sigma^{2}$ for REF-B2 and fODS in the t-test is obtained from the TSAM 95\% prediction interval $I$, following the relation $\sigma^{2}=(\operatorname{I~SQRT}(n) / 2 \times 1.96)^{2}$, where $n$ is the number of models in the multi-model mean. The outcome of the t-tests is discussed using the terminology of the IPCC (see Box TS.1 of Solomon et al., 2007) to indicate the assessed likelihood: if the confidence level from the t-test is $>95 \%$, then it is extremely likely that full ozone recovery has occurred (within $2 \sigma$ confidence), if it is $>90 \%$ it is very likely that it has occurred, while if it is $>66 \%$ it is likely that it has occurred (within $1 \sigma$ confidence). For values between $33 \%$ and $66 \%$ probability it is about as likely as not and for values $<33 \%$ it is unlikely that full recovery of ozone has occurred.

Figure 10 shows the date of return to 1960 (upper panel) and 1980 (lower panel) total column ozone compared to the return date of $\mathrm{Cl}_{\mathrm{y}}$ at $50 \mathrm{hPa}$ and $\mathrm{ESC}$ at $50 \mathrm{hPa}$ for the annual average (global, tropical and midlatitude) and spring (polar) total ozone column derived from the MMT (large triangles) of the CCMVal-2 reference simulations (17 CCMs) in each latitude band. Note that the return dates differ slightly from return dates derived from the MMT in Fig. 6 where in the multi-model mean only a subset of the $17 \mathrm{CCMs}$ are considered. They also differ from Chapter 9 of SPARC CCMVal (2010) that used only 16 out of the 17 CCMs used here. The MMT ESC at $50 \mathrm{hPa}$ is calculated as $\mathrm{Cl}_{\mathrm{y}}+60 \times \mathrm{Br}_{\mathrm{y}}$ except for one model (E39CA) where $\mathrm{Cl}_{\mathrm{y}}$ instead of ESC was used. This model does not have available separate information about $\mathrm{Br}_{\mathrm{y}}$, since it applies a bromine parameterisation (see Appendix of Stenke et al., 2009).

There is no consensus between CCMs on whether tropical total column ozone will return to 1980 values, with some models showing ozone increasing slightly above 1980 values by the second half of the 21st century and others with ozone
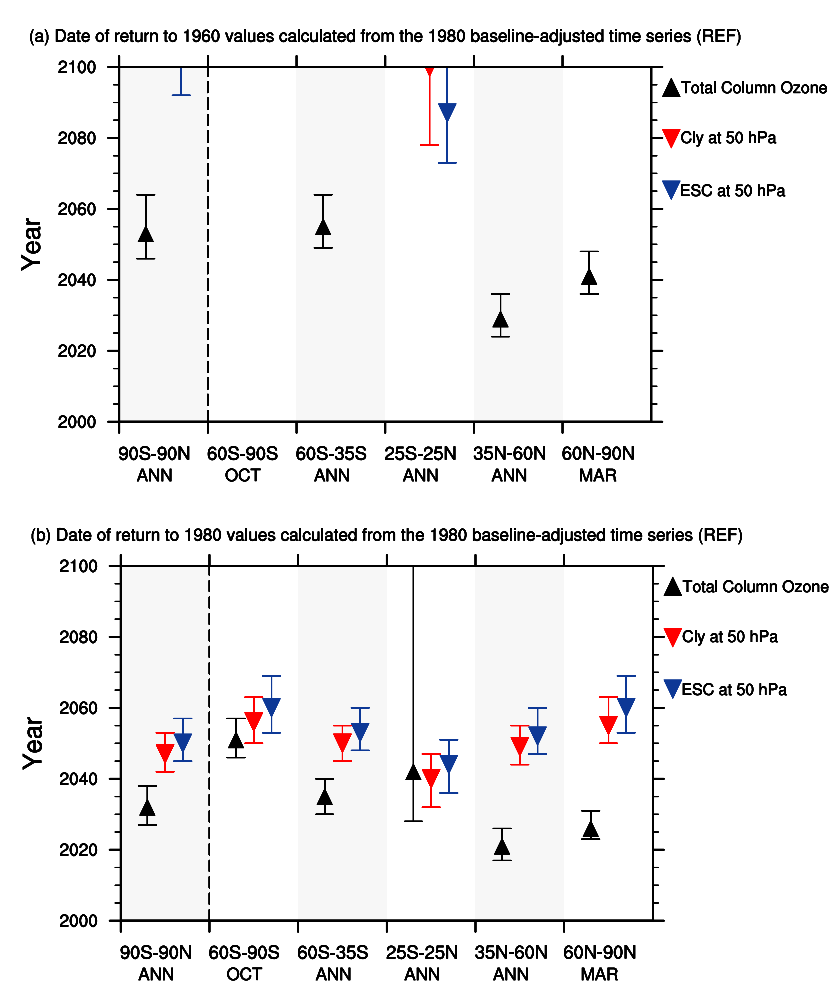

Fig. 10. Date of return to 1960 (upper panel) and 1980 (lower panel) total column ozone (black triangle and error bar), $\mathrm{Cl}_{\mathrm{y}}$ at $50 \mathrm{hPa}$ (red triangle and error bar) and ESC at $50 \mathrm{hPa}$ (blue triangle and error bar) for the annual average (global, tropical and midlatitude) and spring (polar) total column ozone derived from the 1980 baselineadjusted CCMVal-2 reference simulations (17 CCMs) in each latitude band. The error bar shows the uncertainty in return dates as calculated from the $95 \%$ confidence interval. ESC is calculated as $\mathrm{Cl}_{\mathrm{y}}+60 \times \mathrm{Br}_{\mathrm{y}}$ except for E39CA (see text). While a few models project a return of tropical total column ozone to 1980 levels, most do not with the result that the 95\% TSAM confidence interval extends from 2030 to beyond the end of the century which explains the large error bar in the tropical column ozone return dates in the lower panel.

remaining below 1980 values through the 21 st century (see Austin et al., 2010; Chapter 9 of SPARC CCMVal, 2010). This is reflected by the large error bar derived from the $95 \%$ TSAM confidence interval which extends from around 2030 to beyond the end of the century. However, unlike in studies mentioned above which included 16 out of the 17 CCM REFB2 simulations used here, the addition of one model (EMACFUB) in this study, a model which returns to 1980 values earlier than the MMT in the tropics, causes the MMT to return to its 1980 value in 2041. Note also that tropical column ozone derived from the subset of 9 CCMs in Fig. 6b does also not return to its 1980 value, showing again that the tropical ozone return date is not a robust quantity across the CCMs. However, there is a consensus in all CCMs that tropical column ozone will not return to 1960 values, i.e. even when strato- 
spheric halogens return to historical (1960) values tropical column ozone will remain below its historical values due to the increase in tropical upwelling (see Fig. 10a and Chapter 9 of SPARC CCMVal, 2010). In contrast, $\mathrm{Cl}_{\mathrm{y}}$ and ESC in the tropical region return to 1980 values faster than in all other regions (Fig. 10b) with only minor difference between them. By the end of the century, it is likely $(\sim 82 \%)$ that full recovery of tropical column ozone from the effects of ODSs will have occurred, while the $1 \sigma$ confidence level $(66 \%)$ is projected to be reached already $\sim 2074$ (see Table 5). Column ozone in the tropics is projected to decrease again in the 2 nd half of the 21 st century due to climate change (see Sect. 4.1). In the upper tropical stratosphere, ozone returns to 1980 values at $\sim 2020$ which is faster than in other regions (see Fig. 2a), while it is about as likely as not $(\sim 42 \%)$ that full ozone recovery has occurred by the end of the 21 st century (see Table 5). In the lower tropical stratosphere however, ozone never returns to its 1980 values. That said, because ozone in this region is little affected by ODSs, the recovery of ozone from ODS effects is identified above the $1 \sigma$ confidence level $(66 \%)$ throughout the entire 21 st century, and above the $2 \sigma$ confidence level (95\%) from 2040 onwards.

In the northern midlatitudes, total column ozone returns to 1980 values around 2021 (within a bounded range of 2017 to 2026, see Fig. 10b and Table 3). This is the earliest return in all regions considered here, in agreement with previous studies (e.g., Shepherd, 2008; Austin et al., 2010; Chapter 9 of SPARC CCMVal, 2010). While the qualitative evolution is the same in both hemispheres in the CCMs, the midlatitude anomalies are larger in the $\mathrm{SH}$ and the return of midlatitude column ozone to 1980 values therefore occurs later in the SH ( 2035 within a bounded range of 2030 to 2040) than in the NH. The difference in the date of return to 1980 values appears to be due to inter-hemispheric difference in changes in transport, see discussion in Sect. 4.2. In all CCMs the return of total column ozone to 1980 values in the midlatitudes occurs before that of $\mathrm{Cl}_{\mathrm{y}}$ and ESC ( $\sim 2050$ in both hemispheres). In contrast, in the northern midlatitudes it is likely (71\%) that full recovery of total column ozone has occurred by the end of the 21 st century, while it is about as likely as not (61\%) in the southern midlatitudes (Fig. 6c, d and Table 5). In both hemispheres, midlatitude column ozone also returns to 1960 values, but significantly later than when it returns to 1980 values ( 2055 in $\mathrm{SH}$ and $\sim 2030$ in $\mathrm{NH}$ ). In the midlatitude upper stratosphere, ozone returns to 1980 values $\sim 2030$ (see Fig. 2c, e), while in both hemispheres full recovery of ozone from ODSs in this region of the atmosphere is projected to not likely have occurred by 2100 (see Table 5). In the midlatitude lower stratosphere, ozone returns to its 1980 values $\sim 2055$, while full ozone recovery at the $1 \sigma$ confidence interval is reached $\sim 2042$ in the $\mathrm{NH}$ and $\sim 2073$ in the SH. By the end of the century, full ozone recovery is projected to have likely occurred in the northern and southern midlatitude lower stratosphere $(\sim 85 \%$ and $82 \%$, respectively).
As discussed in Sect. 4.3, Antarctic spring ozone column evolution is dominated by ODSs, and in this region ozone return dates are very similar to $\mathrm{Cl}_{\mathrm{y}}$ and ESC return dates and occur later than in all other regions. Column ozone is therefore projected to return to its 1980 values around 2051 (within a bounded range of 2046 to 2057, see Table 3 and Fig. 10b). There is however a spread in the magnitude of the changes among the CCMs which can also be seen by the 95\% confidence interval of the MMT (Fig. 6f) and by the uncertainty in the time of return to 1980 values. This spread is closely linked to the spread in simulated $\mathrm{Cl}_{\mathrm{y}}$ (Chapter 9 of SPARC CCMVal, 2010). On the other hand, it is about as likely as not $(62 \%)$ that full ozone recovery in the reference simulations has occurred by the end of the 21 st century (compare fODS with REF-B2 in Fig. 6f, see also Table 5), and column ozone has also not returned to its 1960 values by then (Fig. 10a).

In contrast, in the Arctic, total column ozone is projected to return to its 1980 values already around 2026 (within a bounded range of 2023 to 2031), which is much earlier than when $\mathrm{Cl}_{\mathrm{y}}$ and $\mathrm{ESC}$ return to 1980 values in this region, and it is also projected to return to its 1960 values $(\sim 2041)$. Full recovery of total column ozone at the $1 \sigma$ confidence level $(66 \%)$ in the Arctic is reached earlier than in all other regions $(\sim 2038)$ and it is likely that ozone has fully recovered $(\sim 84 \%)$ by the end of the century (Fig. 6e and Table 5). Global total column ozone returns to its 1980 values around 2032 (within a bounded range of 2027 to 2038), which is earlier than global $\mathrm{Cl}_{\mathrm{y}}$ or $\mathrm{ESC}$ at $50 \mathrm{hPa}$ (Fig. 10b), while it is about as likely as not (54\%) that full ozone recovery has occurred by the end of the century (Fig. 6a).

Overall, total column ozone returns to its 1980 values in all regions, with largest uncertainty in the ozone return date estimate in the tropics, while by 2100 it returns to its 1960 values only in the midlatitudes and in the Arctic, but not over Antarctica and not in the tropics. Full recovery of ozone is projected to not likely have occurred by the end of the century in any of the upper stratosphere regions. In the tropical lower stratosphere $(50 \mathrm{hPa})$, however, it is projected to be very likely that full ozone recovery from ODSs has occurred by the end of the $21 \mathrm{st}$ century while it is likely that it occurred also over midlatitudes. For total column ozone, full ozone recovery is not reached at the $2 \sigma$ confidence level in any of the regions, while at the $1 \sigma$ level it is projected to occur $\sim 2038$ in the Arctic, $\sim 2070$ at northern midlatitudes, and $\sim 2074$ in the tropics, but not in the southern midlatitudes and not over Antarctica. In the southern midlatitudes and in the Antarctic it is still not likely that ozone has fully recovered from ODSs by the end of the century ( $61 \%$ and $62 \%$, respectively). The larger set of models used here confirms the overall findings of Waugh et al. (2009) who assessed ozone recovery within GEOSCCM. 
Table 5. Level of confidence that full ozone recovery has already occurred at the end of the century (2090-2097) calculated from the student t-test applied to the multi-model means of the fixed ODS simulation (fODS) and the reference simulation (REF-B2), see text for details. If the confidence level is above $66 \%$, then the year when the confidence level reaches $66 \%$ is also added, indicating that full ozone recovery may have occurred within $1 \sigma$ confidence.

\begin{tabular}{llll}
\hline Region & Total column ozone & Ozone at $5 \mathrm{hPa}$ & Ozone at $50 \mathrm{hPa}$ \\
\hline Global annual mean & $54 \%$ & not assessed here & not assessed here \\
Tropics annual mean & $82 \%(66 \%$ in 2074$)$ & $42 \%$ & $93 \%(66 \%$ in all the years $)$ \\
Midlatitude NH annual mean & $71 \%(66 \%$ in 2070$)$ & $25 \%$ & $85 \%(66 \%$ in 2042) \\
Midlatitude SH annual mean & $61 \%$ & $27 \%$ & $82 \%(66 \%$ in 2073) \\
Arctic March mean & $84 \%(66 \%$ in 2038) & $49 \%$ & $91 \%(66 \%$ in 2046) \\
Antarctic October mean & $62 \%$ & $68 \%$ & $56 \%$ \\
\hline
\end{tabular}

\section{Discussion and conclusions}

In this paper projections of stratospheric ozone throughout the 21st century have been examined from a suite of chemistry-climate models (CCMs). In the future reference simulations (REF-B2) that were provided by 17 CCMs, surface halogenated ozone depletion substances (ODSs) are prescribed according to the adjusted A1 halogen scenario of WMO (2007) and long-lived greenhouse gases (GHG) according to the SRES (Special Report on Emission Scenarios) GHG scenario A1B (IPCC, 2000). The reference simulations were compared to sensitivity simulations with either ODS or GHG concentrations fixed at 1960 levels, which were performed by a subset of models ( 9 and 7 CCMs, respectively) to disaggregate the drivers of projected ozone changes. These simulations were also used to assess the two distinct milestones of ozone returning to historical values (ozone return dates) and ozone no longer being discernibly influenced by ODSs (full ozone recovery). This study therefore extends the analysis on ozone projections of Chapter 9 of SPARC CCMVal (2010) and Austin et al. (2010) and the study by Waugh et al. (2009) who assessed full ozone recovery using a single model.

In the tropical and midlatitude upper stratosphere ozone in the reference simulations decreases between 1960 and 2000 in response to increasing equivalent stratospheric chlorine (ESC), followed by a steady increase until the end of the 21st century, in agreement with previous results (e.g. Waugh et al., 2009; Oman et al., 2010b). However, as ESC decreases from 2000 to 2100 ozone does not simply retrace the 1960 2000 path but, as a result of $\mathrm{CO}_{2}$-induced stratospheric cooling, shows systematically elevated ozone through the 21 st century such that ozone returns to 1980 values in the 2020 s well before ESC returns to its 1980 value in the mid-2050s. By 2100 ozone is still being influenced by ESC and hence full recovery of ozone from ODSs in this region of the atmosphere is projected to not likely have occurred by 2100 . In the tropical lower stratosphere, a robust result simulated by CCMs is a steady decline of ozone from 1960 to 2100 due to increased tropical upwelling that has also been shown in previous studies using a smaller subset of CCMs (e.g. Eyring et al., 2007; WMO, 2007; Butchart et al., 2010; SPARC CCMVal, 2010). Ozone in the simulation with fixed ODSs is nearly identical to REF-B2, confirming again that in the tropical lower stratosphere ozone shows little response to ODSs. Although ozone decreases continuously from 1960 to 2100 , the tropical lower stratosphere is together with the Arctic lower stratosphere the only region where ozone has very likely fully recovered from the effects of ODSs. In the lower midlatitude stratosphere the evolution differs from that in the tropics, and rather than a steady decrease of ozone, first a decrease of ozone is simulated between 1960 and 2000, which is then followed by a steady increase throughout the 21 st century. Ozone in the midlatitude lower stratosphere returns to its 1980 levels $\sim 2045$ in the $\mathrm{NH}$ and $\sim 2055$ in the $\mathrm{SH}$, and full ozone recovery is likely reached by 2100 in both hemispheres.

Projected tropical total column ozone changes are in general small compared to extra-tropical regions $(\sim 7 \mathrm{DU}$ in the reference simulations). Model uncertainty in tropical column evolution is high (see also Charlton-Perez et al., 2010), mostly related to the large spread that is simulated in the magnitude of tropical upwelling among the CCMVal-2 models (see also Butchart et al., 2010 and Chapter 4 of SPARC CCMVal 2010). Unlike in Chapter 9 of SPARC CCMVal (2010) where 16 out of the 17 CCMs used here were included, the addition of one CCM caused the multi-model mean of the $17 \mathrm{CCMs}$ to return to its 1980 value in the tropics, showing that the ozone return date is not a robust quantity in the tropics, given the large spread that is simulated by the individual models. Over northern midlatitudes total column ozone returns to 1980 values in the mid-2020s in the reference simulations, well before ESC returns to its 1980 value in the late 2040s. Similarly, over southern midlatitudes total column ozone returns to 1980 values in the mid-2030s (a decade later than in the Northern Hemisphere), and well before ESC returns to its 1980 value in the early 2050s. By 2100 total column ozone over midlatitudes is still influenced 
by ESC and full recovery of column ozone has likely occurred in the northern midlatitudes while it has not likely occurred in the southern midlatitudes.

Unlike the midlatitudes and Arctic, the total column ozone evolution over Antarctica in October shows small sensitivity to changes in GHGs with the return path (21st century) closely tracking the outbound path (20th century). By the end of the century it is still unlikely that total column ozone has fully recovered from ODSs. In the Arctic $\left(60^{\circ}-90^{\circ} \mathrm{N}\right)$ in March, total column ozone follows a similar evolution to spring-time Antarctic ozone, but with smaller ozone losses during the peak ozone depletion period and with ozone increasing significantly above 1980 and even 1960 values at the end of the century in the reference, but not in the fixed GHG simulation, indicating that climate change plays a significant role. As for the midlatitudes, total column ozone over the Arctic is elevated above what would be expected from changes in $\mathrm{ESC}$ by $\mathrm{CO}_{2}$-induced stratospheric cooling and changes in transport. In the Arctic it is likely ( $>66 \%$ ) that full recovery of total column ozone from the effects of ODS will have occurred by about 2038 . However, at no time before 2100 is it very likely ( $>90 \%$ ) that full recovery will have occurred.

It is important to note that the future ozone evolution as well as the two milestones of ozone returning to its historical values and ozone recovering from the influence of ODSs have been studied here using a single GHG scenario. However, the SRES A1B scenario that was used in the CCMVal-2 reference simulations is not the only plausible GHG scenario for the future (IPCC, 2000; Moos et al., 2008). Given the importance of GHG-induced changes on stratospheric temperatures, chemistry, circulation and transport on the evolution of ozone through the 21 st century shown here and in previous studies, it is likely that the importance of the factors affecting ozone and the resulting future ozone evolution will be different under a different GHG scenario (see also Charlton-Perez et al., 2010; Eyring et al., 2010; Oman et al., 2010a). Likewise, the future ozone evolution would be different for different ODSs scenarios (see for example the extreme "world avoided" scenarios that were studied by Morgenstern et al., 2008 and Newman et al., 2009). In addition, since all the CCMs used here are forced by specifying mixing ratios of ODSs at the surface rather than specifying emissions, the flux of halogen source gases entering the stratosphere is highly constrained and therefore the evolution of the ESC loading is expected to be similar in the CCMs (see Chapter 6 of SPARC CCMVal, 2010). In reality, surface source gas levels should be determined by emission fluxes and rates of loss processes which could increase the spread in modeled halogen loadings and hence in stratospheric ozone losses (Douglass et al., 2008). Other uncertainties in the ozone projections could stem from prescribed sea surface temperatures and sea ice concentrations, missing tropospheric chemistry, model parameterizations, and model climate sensitivity as well as from the neglect of additional bromine from very short-lived substances (VSLS) (Sinnhuber et al., 2005; Chapter 2 of WMO, 2007). The neglect of VSLS could result in a substantial fractional increase to the amount of bromine in the lowermost stratosphere as upwelling changes (Gettelman et al., 2009), with important consequences for ozone trends and the photochemical budget of ozone.

\section{Supplementary material related to this article is available online at: http://www.atmos-chem-phys.net/10/9451/2010/ acp-10-9451-2010-supplement.zip.}

Acknowledgements. We acknowledge the Chemistry-Climate Model Validation (CCMVal) Activity for WCRP's (World Climate Research Programme) SPARC (Stratospheric Processes and their Role in Climate) project for organizing and coordinating the model data analysis activity, and the British Atmospheric Data Center (BADC) for collecting and archiving the CCMVal model output. We thank John Austin (AMTRAC3, NOAA GFDL, USA), Martine Michou and Hubert Teyssedre (CNRM-ACM, Meteo-France, France) for supplying model data from the REF-B2 reference simulations. We thank David B. Stephenson (Mathematics Research Institute, University of Exeter, UK) for his work on the TSAM method. CCSRNIES research was supported by the Global Environmental Research Found of the Ministry of the Environment of Japan (A-071) and the simulations were completed with the super computer at CGER, NIES. The MRI simulation was made with the supercomputer at the National Institute for Environmental Studies, Japan. The MetOffice simulation was supported by the Joint DECC and Defra Integrated Climate Programme, DECC/Defra (GA01101). NCAR is operated by the University Corporation for Atmospheric Research under sponsorship of the National Science Foundation.

Edited by: T. J. Dunkerton

\section{References}

Akiyoshi, H., Zhou, L. B., Yamashita, Y., Sakamoto, K., Yoshiki, M., Nagashima, T., Takahashi, M., Kurokawa, J., Takigawa, M., and Imamura, T.: A CCM simulation of the breakup of the Antarctic polar vortex in the years 1980-2004 under the CCMVal scenarios, J. Geophys. Res., 114, D03103, doi:10.1029/2007JD009261, 2009.

Akiyoshi, H., Yamashita, Y., Sakamoto, K., Zhou, L. B., and Imamura, T.: Recovery of stratospheric ozone in calculations by the CCSR/NIES CCM under the CCMVal-REF2 scenario and a no-climate-change run, J. Geophys. Res., doi:10.1029/2009JD012683, in press, 2010.

Austin, J. and Wilson, R. J.: Sensitivity of polar ozone to sea surface temperatures and halogen amounts, J. Geophys. Res., 115, D18303, doi:10.1029/2009JD013292, 2010.

Austin, J., Scinocca, J., Plummer, D., Oman, L., Waugh, D., Akiyoshi, H., Bekki, S., Braesicke, P., Butchart, N., Chipperfield, M., Cugnet, D., Dameris, M., Dhomse, S., Eyring, V., Frith, S., Garcia, R. R., Garny, H., Gettelman, A., Hardiman, S. C., Kinnison, D., Lamarque, J. F., Mancini, E., Marchand, M., Mi- 
chou, M., Morgenstern, O., Nakamura, T., Pawson, S., Pitari, G., Pyle, J., Rozanov, E., Shepherd, T. G., Shibata, K., Stolarski, R., Teyssedre, H., Wilson, R. J., and Yamashita, Y.: The decline and recovery of total column ozone using a multi-model time series analysis, J. Geophys. Res., doi:10.1029/2010JD013857, in press, 2010.

Avallone, L. M. and Prather, M. J., Photochemical evolution of ozone in the lower tropical stratosphere, J. Geophys. Res., 101, 1457-1461, 1996.

Bell, C. J., Gray, L. J., and Kettleborough, J.: Changes in Northern Hemisphere stratospheric variability under increased $\mathrm{CO}_{2}$ concentrations, Q. J. Roy. Meteorol. Soc., 136, 1181-1190, 2010.

Butchart, N., Scaife, A. A., Bourqui, M., de Grandpré, J., Hare, S. H. E., Kettleborough, J., Langematz, U., Manzini, E., Sassi, F., Shibata, K., Shindell, D., and Sigmond, M.: Simulations of anthropogenic change in the strength of the Brewer-Dobson circulation, Clim. Dyn., 27, 727-741, doi:10.1007/s00382-006-01624, 2006.

Butchart, N., Cionni, I., Eyring, V., Shepherd, T. G., Waugh, D. W., Akiyoshi, H., Austin, J., Brühl, C., Chipperfield, M. P., Cordero, E., Dameris, M., Deckert, R., Dhomse, S., Frith, S. M., Garcia, R. R., Gettelman, A., Giorgetta, M. A., Kinnison, D. E., Li, F., Mancini, E., McLandress, C., Pawson, S., Pitari, G., Plummer, D. A., Rozanov, E., Sassi, F., Scinocca, J. F., Shibata, K., and Tian, W.: Chemistry-climate model simulations of $21 \mathrm{st}$ century stratospheric climate and circulation changes, J. Clim., doi:10.1175/2010JCLI3404.1, in press, 2010.

Charlton-Perez, A. J., Hawkins, E., Eyring, V., Cionni, I., Bodeker, G. E., Kinnison, D. E., Akiyoshi, H., Frith, S.M., Garcia, R., Gettelman, A., Lamarque, J.F., Pawson, S., Stolarski, R. S., Austin, J., Bekki, S., Braesicke, P., Chipperfield, M., Dhomse, S., Mancini, E., Michou, M., Morgenstern, O., Pitari, G., Plummer, D., Pyle, J. A., Rozanov, E., Scinocca, J., Shibata, K., Shepherd, T. G., Teyssedre, H., Tian, W., and Waugh,D.W.: The potential to narrow uncertainty in projections of stratospheric ozone over the 21 st century, Atmos. Chem. Phys., 10, 94739486, doi:10.5194/acp-10-9473-2010, 2010

Chipperfield, M. P. and Feng, W.: Comment on: "Stratospheric Ozone Depletion at northern mid-latitudes in the 21st century: The importance of future concentrations of greenhouse gases nitrous oxide and methane", Geophys. Res. Lett., 30, 1389, doi:10.1029/2002GL016353, 2003.

Clough, S. and Iacono, M.: Line-by-line calculation of atmospheric fluxes and cooling rates. 2. Application to carbon dioxide, ozone, methane, nitrous oxide and the halocarbons, J. Geophys. Res., 100(D8), 16519-16535, 1995.

Deckert, R. and Dameris, M.: Higher tropical SSTs strengthen the tropical upwelling via deep convection, Geophys. Res. Lett., 35, L10813, doi:10.1029/2008GL033719, 2008a.

Deckert, R. and Dameris, M.: From ocean to stratosphere, Science, 322, 5698, 53-55, doi:10.1126/science.1163709, 2008b.

deGrandpre, J., Beagley, S. R., Fomichev, V. I., Griffioen, E., McConnell, J. C., Medvedev, A. S., and Shepherd, T. G.: Ozone climatology using interactive chemistry: Results from the Canadian Middle Atmosphere Model, J. Geophys. Res., 105, 2647526491, 2000.

Déqué, M.: Frequency of precipitation and temperature extremes over France in an anthropogenic scenario: model results and statistical correction according to observed values, Global Planet.
Change, 57, 16-26, 2007.

Douglass, A. R., Stolarski, R. S., Schoeberl, M. R., Jackman, C. H., Gupta, M. L., Newman, P. A., Nielsen, J. E., and Fleming, E. L.: Relationship of loss, mean age of air and the distribution of CFCs to stratospheric circulation and implications for atmospheric lifetimes, J. Geophys. Res., 113, D14309, doi:10.1029/2007JD009575, 2008.

Egorova, T., Rozanov, E., Zubov, V., Manzini, E., Schmutz, W., and Peter, T.: Chemistry-climate model SOCOL: a validation of the present-day climatology, Atmos. Chem. Phys., 5, 1557-1576, doi:10.5194/acp-5-1557-2005, 2005.

Eyring, V.,. Harris, N. R. P, Rex, M., Shepherd, T. G., Fahey, D. W., Amanatidis, G. T., Austin, J., Chipperfield, M. P., Dameris, M., De F. Forster, P. M., Gettelman, A., Graf, H. F., Nagashima, T., Newman, P. A., Pawson, S., Prather, M. J., Pyle, J. A., Salawitch, R. J., Santer, B. D., and Waugh, D. W.: A strategy for processoriented validation of coupled chemistry-climate models, B. Am. Meteorol. Soc., 86, 1117-1133, 2005.

Eyring, V., Butchart, N., Waugh, D. W., Akiyoshi, H., Austin, J., Bekki, S., Bodeker, G. E., Boville, B. A., Brühl, C., Chipperfield, M. P., Cordero, E., Dameris, M., Deushi, M., Fioletov, V. E., Frith, S. M., Garcia, R. R., Gettelman, A., Giorgetta, M. A., Grewe, V., Jourdain, L., Kinnison, D. E., Mancini, E., Manzini, E., Marchand, M., Marsh, D. R., Nagashima, T., Newman, P. A., Nielsen, J. E., Pawson, S., Pitari, G., Plummer, D. A., Rozanov, E., Schraner, M., Shepherd, T. G., Shibata, K., Stolarski, R. S., Struthers, H., Tian, W., and Yoshiki, M.: Assessment of temperature, trace species and ozone in chemistry-climate model simulations of the recent past, J. Geophys. Res., 111, D22308, doi:10.1029/2006JD007327, 2006.

Eyring, V., Waugh, D. W., Bodeker, G. E., Cordero, E., Akiyoshi, H., Austin, J., Beagley, S. R., Boville, B., Braesicke, P., Brühl, C., Butchart, N., Chipperfield, M. P., Dameris, M., Deckert, R., Deushi, M., Frith, S. M., Garcia, R. R., Gettelman, A., Giorgetta, M., Kinnison, D. E., Mancini, E., Manzini, E., Marsh, D. R., Matthes, S., Nagashima T., Newman, P. A., Nielsen, J. E., Pawson, S., Pitari, G., Plummer, D. A., Rozanov, E., Schraner, M., Scinocca, J. F., Semeniuk K., Shepherd, T. G., Shibata, K., Steil, B., Stolarski, R., Tian, W., and Yoshiki, M.: Multimodel projections of stratospheric ozone in the 21 st century, J. Geophys. Res., 112, D16303, doi:10.1029/2006JD008332, 2007.

Eyring, V., Chipperfield, M. P., Giorgetta, M. A., Kinnison, D. E., Manzini, E., Matthes, K., Newman, P. A., Pawson, S., Shepherd, T. G., and Waugh, D. W.: Overview of the New CCMVal Reference and Sensitivity Simulations in Support of Upcoming Ozone and Climate Assessments and the Planned SPARC CCMVal Report, SPARC Newsletter No. 30, 20-26, 2008.

Eyring, V., Cionni, I., Lamarque, J. F., Akiyoshi, H., Bodeker, G. E., Charlton-Perez, A. J., Frith, S. M., Gettelman, A., Kinnison, D. E., Nakamura, T., Oman, L. D., Pawson, S., and Yamashita, Y.: Sensitivity of 21st century stratospheric ozone to greenhouse gas scenarios, Geophys. Res. Lett., 37, L16807, doi:10.1029/2010GL044443, 2010.

Fomichev, V. I., Jonsson, A. I., de Grandpré, J., Beagley, S. R., McLandress, C., Semeniuk, K., and Shepherd, T. G.: Response of the middle atmosphere to $\mathrm{CO}_{2}$ doubling: Results from the Canadian Middle Atmosphere Model, J. Clim., 20, 1121-1144, 2007.

Garcia, R. R. and Randel, W. J.: Acceleration of the Brewer-Dobson 
Circulation due to Increases in Greenhouse Gases, J. Atmos. Sci., 65, 2731-2739, 2008.

Garcia, R. R., Marsh, D. R., Kinnison, D. E., Boville, B. A., and Sassi, F.: Simulation of secular trends in the middle atmosphere, 1950-2003, J. Geophys. Res., 112, D09301, doi:10.1029/2006JD007485, 2007.

Garny, H., Dameris, M., and Stenke, A.: Impact of prescribed SSTs on climatologies and long-term trends in CCM simulations, Atmos. Chem. Phys., 9, 6017-6031, doi:10.5194/acp-9-6017-2009, 2009.

Gettelman, A., Lauritzen, P. H., Park, M., and Kay, J. E.: Processes regulating short-lived species in the tropical tropopause layer, J. Geophys. Res., 114, D13303, doi:10.1029/2009JD011785, 2009.

Haigh, J. D. and Pyle, J. A.: Ozone perturbation experiments in a two-dimensional circulation model,Q. J. Roy. Meteorol. Soc., 108, 551-574, 1982.

IPCC (Intergovernmental Panel on Climate Change): Special report on emissions scenarios: a special report of Working Group III of the Intergovernmental Panel on Climate Change, 599 pp., Cambridge University Press, Cambridge, UK, 2000.

IPCC (Intergovernmental Panel on Climate Change): Climate Change 2007: The Physical Science Basis: Contribution of Working Group I to the Fourth Assessment Report of the Intergovernmental Panel on Climate Change, edited by: Solomon, S., Qin, D., Manning, M., Chen, Z., Marquis, M., Averyt, K. B., Tignor, M., and Miller, H. L., 996 pp., Cambridge University Press, Cambridge, UK, and New York, NY, 2007.

Jöckel, P., Tost, H., Pozzer, A., Brühl, C., Buchholz, J., Ganzeveld, L., Hoor, P., Kerkweg, A., Lawrence, M. G., Sander, R., Steil, B., Stiller, G., Tanarhte, M., Taraborrelli, D., van Aardenne, J., and Lelieveld, J.: The atmospheric chemistry general circulation model ECHAM5/MESSy1: consistent simulation of ozone from the surface to the mesosphere, Atmos. Chem. Phys., 6, 50675104, doi:10.5194/acp-6-5067-2006, 2006.

Jonsson, A. I., de Grandpré, J., Fomichev, V. I., McConnell, J. C., and Beagley, S. R.: Doubled $\mathrm{CO}_{2}$-induced cooling in the middle atmosphere: Photochemical analysis of the ozone radiative feedback, J. Geophys. Res., 109, D24103, doi:10.1029/2004JD005093, 2004.

Jourdain, L., Bekki, S., Lott, F., and Lefèvre, F.: The coupled chemistry-climate model LMDz-REPROBUS: description and evaluation of a transient simulation of the period 1980-1999, Ann. Geophys., 26, 1391-1413, doi:10.5194/angeo-26-13912008, 2008.

Kärcher, B. and Lohmann, U.: A Parameterization of cirrus cloud formation: Homogeneous freezing of supercooled aerosols, J. Geophys. Res. 107(D2), 4010, doi:10.1029/2001JD000470, 2002.

Lamarque, J.-F., Kinnison, D. E., Hess, P. G., and Vitt, F. M.: Simulated lower stratospheric trends between 1970 and 2005: Identifying the role of climate and composition changes, J. Geophys. Res., 113, D12301, doi:10.1029/2007JD009277, 2008.

Li, F., Austin, J., and Wilson, J.: The Strength of the BrewerDobson Circulation in a Changing Climate: Coupled ChemistryClimate Model Simulation, J. Climate, 21, 40-57, 2008.

Li, F., Stolarski, R. S., and Newman, P. A.: Stratospheric ozone in the post-CFC era, Atmos. Chem. Phys., 9, 2207-2213, doi:10.5194/acp-9-2207-2009, 2009.

McLandress, C., Jonsson, A. I., Plummer, D. A., Reader, M.
C., Scinocca, J. F., and Shepherd, T. G.: Separating the effects of climate change and ozone depletion on the dynamics of the Southern Hemisphere stratosphere, J. Climate, doi: 10.1175/2010JCLI3586.1, in press, 2010.

Montzka, S. A., Butler, J. H., Hall, B. D., Mondeel, D. J., and Elkins, J. W.: A decline in tropospheric bromine, Geophys. Res. Lett., 30, 1826, doi:10.1029/2003GL017745, 2003.

Morgenstern, O., Braesicke, P., Hurwitz, M. M., O’Connor, F. M., Bushell, A. C., Johnson, C. E., and Pyle, J. A.: The World Avoided by the Montreal Protocol, Geophys. Res. Lett., 35, L16811, doi:10.1029/2008GL034590, 2008.

Morgenstern, O., Braesicke, P., O’Connor, F. M., Bushell, A. C., Johnson, C. E., Osprey, S. M., and Pyle, J. A.: Evaluation of the new UKCA climate-composition model. Part 1: The stratosphere, Geosci. Model Dev., 1, 43-57, 2009.

Morgenstern, O., Giorgetta, M. A., Shibata, K., Eyring, V., Waugh, D. W., Shepherd, T. G., Akiyoshi, H., Austin, J., Baumgaertner, A. J. G., Bekki, S., Braesicke, P., Brühl, C., Chipperfield, M. P., Cugnet, D., Dameris, M., Dhomse, S., Frith, S. M., Garny, H., Gettelman, A., Hardiman, S. C., Hegglin, M. I., Kinnison, D. E., Lamarque, J.-F., Mancini, E., Manzini, E., Marchand, M., Michou, M., Nakamura, T., Nielsen, J. E., Pitari, G., Plummer, D. A., Rozanov, E., Scinocca, J. F., Smale, D., Teyssedre, H., Toohey, M., Tian, W., and Yamashita, Y.: Review of the formulation of present-generation stratospheric chemistry-climate models and associated external forcings, J. Geophys. Res., 115, D00M02, doi:10.1029/2009JD013728, 2010.

Moss, T., Babiker, M., Brinkman, S., Calvo, E., Carter, T., Edmonds, J., Elgizouli, I., Emori, S., Erda, L., Hibbard, K., Jones, R. , Kainuma, M., Kelleher, J., Lamarque, J.-F., Manning, M., Matthews, B., Meehl, G., Meyer, L., Mitchell, J., Nakic'enovic', N., O’Neill, B., Pichs, T., Riahi, K., Rose, S., Runci, P., Stouffer, R., van Vuuren, D., Weyant, J., Wilbanks, T., van Ypersele, J. P., and Zurek, M.: Towards New Scenarios for Analysis of Emissions, Climate Change, Impacts, and Response Strategies., Intergovernmental Panel on Climate Change, Geneva, 132 pp., available at: http://www.aimes.ucar.edu/docs/, 2008.

Newman, P. A., Oman, L. D., Douglass, A. R., Fleming, E. L., Frith, S. M., Hurwitz, M. M., Kawa, S. R., Jackman, C. H., Krotkov, N. A., Nash, E. R., Nielsen, J. E., Pawson, S., Stolarski, R. S., and Velders, G. J. M.: What would have happened to the ozone layer if chlorofluorocarbons (CFCs) had not been regulated?, Atmos. Chem. Phys., 9, 2113-2128, doi:10.5194/acp-9-2113-2009, 2009.

Nissen, K. M., Matthes, K., Langematz, U., and Mayer, B.: Towards a better representation of the solar cycle in general circulation models, Atmos. Chem. Phys., 7, 5391-5400, doi:10.5194/acp-75391-2007, 2007.

Oman, L., Waugh, D. W., Pawson, S., Stolarski, R. S., and Newman, P. A.: On the influence of anthropogenic forcings on changes in the stratospheric mean age, J. Geophys. Res., 114, D03105, doi:10.1029/2008JD010378, 2009.

Oman, L. D., Waugh, D. W., Kawa, S. R., Stolarski, R. S., Douglass, A. R., and Newman, P. A.: Mechanisms and feedback causing changes in upper stratospheric ozone in the 21 st century, J. Geophys. Res., 115, D05303, doi:10.1029/2009JD012397, 2010a.

Oman, L. D., Plummer, D., Waugh, D. W., Austin, J., Scinocca, J., Douglass, A. R., Salawitch, R. J., Akiyoshi, H., Bekki, S., Braesicke, P., Butchart, N., Chipperfield, M., Dhomse, S., 
Eyring, V., Frith, S., Garcia, R. R., Gettelman, A., Hardiman, S. C., Kinnison, D., Lamarque, J. F., Mancini, E., Marchand, M., Michou, M., Morgenstern, O., Pawson, S., Pitari, G., Peter, T., Pyle, J., Rozanov, E., Shepherd, T. G., Shibata, K., Stolarski, R., Teyssedre, H., and Tian, W.: Multi-model assessment of the factors driving the ozone evolution over the 21 st century, J. Geophys. Res., accepted, 2010b.

Pawson, S., Stolarski, R. S., Douglass, A. R., Newman, P. A., Nielsen, J. E., Frith, S. M., and Gupta, M. L.: Goddard Earth Observing System chemistry-climate model simulations of stratospheric ozone-temperature coupling between 1950 and 2005, J. Geophys. Res., 113, D12103, doi:10.1029/2007JD009511, 2008.

Pitari, G., Mancini, E., Rizi, V., and Shindell, D. T.: Impact of Future Climate and Emission Changes on Stratospheric Aerosols and Ozone, J. Atmos. Sci., 59, 414-440, 2002.

Randeniya, L. K., Vohralik, P. F., and Plumb, I. C.: Stratospheric ozone depletion at northern mid latitudes in the 21 st century: The importance of future concentrations of greenhouse gases nitrous oxide and methane, Geophys. Res. Lett., 29(4), 1051, doi:10.1029/2001GL014295, 2002.

Ravishankara, A. R., Daniel, J. S., and Portmann, R. W.: Nitrous Oxide (N2O): The Dominant Ozone-Depleting Substance Emitted in the 21st Century, Science, 326, 123-125, 2009.

Rosenfield, J. E., Douglass, A. R., and Considine, D. B.:The impact of increasing carbon dioxide on ozone recovery, J. Geophys. Res., 107(D6), 4049, doi:10.1029/2001JD000824, 2002.

Schraner, M., Rozanov, E., Schnadt Poberaj, C., Kenzelmann, P., Fischer, A. M., Zubov, V., Luo, B. P., Hoyle, C. R., Egorova, T., Fueglistaler, S., Brnnimann, S., Schmutz, W., and Peter, T.: Technical Note: Chemistry-climate model SOCOL: version 2.0 with improved transport and chemistry/microphysics schemes, Atmos. Chem. Phys., 8, 5957-5974, doi:10.5194/acp-8-59572008, 2008.

Scinocca, J. F., McFarlane, N. A., Lazare, M., Li, J., and Plummer, D.: Technical Note: The CCCma third generation AGCM and its extension into the middle atmosphere, Atmos. Chem. Phys., 8, 7055-7074, doi:10.5194/acp-8-7055-2008, 2008.

Scinocca, J. F., Stephenson, D. B., Bailey, T. C., and Austin, J.: Estimates of past and future ozone trends from multi-model simulations using a flexible smoothing spline methodology, J. Geophys. Res., doi:10.1029/2009JD013622, in press, 2010.

Shepherd, T. G.: Dynamics, Stratospheric Ozone, and Climate Change, Atmos. Ocean, 46, 117-138, 2008.

Shepherd, T. G. and Jonsson, A. I.: On the attribution of stratospheric ozone and temperature changes to changes in ozonedepleting substances and well-mixed greenhouse gases, Atmos. Chem. Phys., 8, 1435-1444, doi:10.5194/acp-8-1435-2008, 2008.

Shibata, K. and Deushi, M.: Long-term variations and trends in the simulation of the middle atmosphere 1980-2004 by the chemistry-climate model of the Meteorological Research Institute, Ann. Geophys., 26, 1299-1326, doi:10.5194/angeo-261299-2008, 2008a.

Shibata, K. and Deushi, M.: Simulation of the stratospheric circulation and ozone during the recent past (1980-2004) with the MRI chemistry-climate model, CGER's Supercomputer Monograph Report Vol.13, National Institute for Environmental Studies, Japan, 154 pp., 2008 b.
Sinnhuber, B.-M., Rozanov, A. Schoede, N., Afe, O. T., Richter, A., Sinnhuber, M. M., Wittrock, F., Burrows, J. P., Stiller, G. P., von Clarmann, T., and Linden, A.: Global observations of stratospheric bromine monoxide from SCIAMACHY, Geophys. Res. Lett., 32, L20810, doi:10.1029/2005GL023839, 2005.

Solomon, S., Qin, D., Manning, M., Alley, R. B., Berntsen, T., Bindoff, N. L., Chen, Z., Chidthaisong, A., Gregory, J. M., Hegerl, G. C., Heimann, M., Hewitson, B., Hoskins, B. J., Joos, F., Jouzel, J., Kattsov, V., Lohmann, U., Matsuno, T., Molina, M., Nicholls, N., Overpeck, J., Raga, G., Ramaswamy, V., Ren, J., Rusticucci, M., Somerville, R., Stocker, T. F., Whetton, P., Wood, R. A., and Wratt, D.: Technical Summary. In: Climate Change 2007: The Physical Science Basis, Contribution of Working Group I to the Fourth Assessment Report of the Intergovernmental Panel on Climate Change, edited by: Solomon, S., Qin, D., Manning, M., Chen, Z., Marquis, M., Averyt, K. B., Tignor, M., and Miller, H. L., Cambridge University Press, Cambridge, United Kingdom and New York, NY, USA, 2007.

SPARC CCMVal: Report on the Evaluation of ChemistryClimate Models, edited by: Eyring, V., Shepherd, T. G., and Waugh, D. W., SPARC Report No. 5, WCRP-132, WMO/TDNo. 1526, available at: http://www.atmosp.physics.utoronto.ca/ SPARC, 2010.

Stenke, A., Dameris, M., Grewe, V., and Garny, H.: Implications of Lagrangian transport for simulations with a coupled chemistry-climate model, Atmos. Chem. Phys., 9, 5489-5504, doi:10.5194/acp-9-5489-2009, 2009.

Teyssèdre, H., Michou, M., Clark, H. L., Josse, B., Karcher, F., Olivié, D., Peuch, V.-H., Saint-Martin, D., Cariolle, D., Attié, J.-L., Nédélec, P., Ricaud, P., Thouret, V., van der A, R. J., VolzThomas, A., and Chéroux, F.: A new tropospheric and stratospheric Chemistry and Transport Model MOCAGE-Climat for multi-year studies: evaluation of the present-day climatology and sensitivity to surface processes, Atmos. Chem. Phys., 7, 58155860, doi:10.5194/acp-7-5815-2007, 2007.

Tian, W. and Chipperfield, M. P.: A new coupled chemistry-climate model for the stratosphere: the importance of coupling for future $\mathrm{O}_{3}$-climate predictions, Q. J. Roy. Meteorol. Soc., 131, 281-303, 2005.

Tian, W., Chipperfield, M. P. , Gray, L. J., and Zawodny, J. M.: Quasi-biennial oscillation and tracer distributions in a coupled chemistry-climate model, J. Geophys. Res., 111, D20301, doi:10.1029/2005JD006871, 2006.

Waugh, D. W., Oman, L., Kawa, S. R., Stolarski, R. S., Pawson, S., Douglass, A. R., Newman, P. A., and Nielsen, J. E.: Impacts of climate change on stratospheric ozone recovery, Geophys. Res. Lett., 36, L03805, doi:10.1029/2008GL036223, 2009.

World Meteorological Organization (WMO)/United Nations Environment Programme (UNEP), Scientific Assessment of Ozone Depletion: 2006, World Meteorological Organization, Global Ozone Research and Monitoring Project, Report No. 50, Geneva, Switzerland, 2007. 